\title{
U.S Agricultural Export Competitiveness and Export Market Diversification
}

\author{
Jaya Jha ${ }^{1,}$, Terry Roe ${ }^{2}$ \\ ${ }^{1}$ Economics Department, Davidson College, North Carolina, USA \\ ${ }^{2}$ Department of Applied Economics, University of Minnesota, St. Paul, USA
}

Email address:

jajha@davidson.edu (J. Jha), troe@umn.edu (T. Roe)

\section{To cite this article:}

Jaya Jha, Terry Roe. U.S Agricultural Export Competitiveness and Export Market Diversification. International Journal of Agricultural Economics. Vol. 6, No. 3, 2021, pp. 122-138. doi: 10.11648/j.ijae.20210603.15

Received: June 3, 2021; Accepted: June 11, 2021; Published: June 21, 2021

\begin{abstract}
This paper examines the structural relationship of foreign GDP growth, real exchange rate volatility, and the impact of exogenous shocks on U.S. agricultural export growth. The intertemporal dynamics of export demand are analyzed within the structural cointegrating vector autoregressive framework. We find that: (1) An increase (decrease) in importing countries' trade-adjusted GDP leads to an increase (decrease) in U.S. agricultural exports; (2) A real appreciation (depreciation) of the U.S. dollar results in a decline (increase) in U.S. agricultural exports; (3) Exports of high-value processed agricultural products are more sensitive to changes in foreign income and exchange rate fluctuations than exports of low-value grains and bulk commodities; (4) In response to exogenous shocks, deviations from the predicted equilibrium level of exports adjust at a much faster rate for exports of grains and other bulk commodities than high-value products; and (5) The present concentration of U.S. agricultural commodity exports to a few developed countries is increasingly problematic, and U.S. agricultural exports may benefit not only from policies intended to increase trade with existing developing country importers but also from policies that aim to export agricultural commodities to emerging markets. The paper not only highlights the importance of including the long-run relationship when modeling short-run dynamics in agricultural trade models, but is also the first to use this method to comprehensively estimate macroeconomic linkages of U.S agricultural exports, simultaneously across a number of agricultural products, importing countries, over a period of five decades.
\end{abstract}

Keywords: Export Demand, Foreign Income, Exchange Rates, Cointegrating VAR, Bounds Test, Income and Price Elasticities

\section{Introduction}

Economic growth in developing countries has been accompanied by a dramatic rise in developing countries' share of world trade [1]. Growth in world food demand, driven by rising incomes is changing both composition and destination of U.S. agricultural exports. U.S. share of global agricultural trade is also sensitive to macroeconomic conditions, particularly the strength of the dollar relative to the currencies of export competitors [2].

High growth in world GDP, particularly in emerging market economies of China, India, and Russia over the 2000-07 period contributed to rising farm income in the U.S. [3]. The U.S. financial crisis of 2008 and the ensuing global economic downturn impacted world demand for U.S. agricultural exports, particularly in developing countries, where demand for food and industrial demand for agricultural products is more responsive to changes in consumer income than in developed countries [3]. More recently, weaker income growth in developing countries, combined with a stronger U.S. dollar and declining oil prices in the 2014-16 period have reduced overall global demand for U.S. agricultural products and made U.S commodity exports less competitive [2].

While the pre-1969 agricultural economics literature largely ignored the importance of exchange rates to agricultural trade, worldwide exchange rate realignment in the early 1970s "disabused economists of the notion that agricultural trade can be studied in isolation from the broader economic environment" [4]. Since Schuh's seminal paper linking low U.S. agricultural exports in the 1950s to an overvalued dollar [5], several studies have attempted to find empirical evidence for the impact of exchange rate volatility 
on agricultural trade, but the conclusions have been mixed ${ }^{1}$. By comparison, empirical estimates of effects on foreign income on U.S. agricultural exports are more consistent, finding strong and statistically significant effects of foreign income on U.S. agricultural exports.

Analysis of factors affecting demand for U.S. agricultural exports allows us to determine the impact of changes in global economic growth on volume of trade with the rest of the world and identify opportunities for U.S. agricultural export market diversification. Shane, Roe, and Somwaru [8] use a dynamic maximizing framework to derive the demand for U.S. agricultural exports as a function of partners' income and real exchange rate. The authors find that episodes of rising U.S. agricultural exports are associated with growth in importing countries' income, whereas episodes of declining exports tend to be dominated by an appreciation of U.S. trade-weighted exchange rate.

Studies investigating the sensitivity of U.S. exports of bulk and consumer-oriented agricultural products to exchange rate volatility have had mixed findings. For example, Baek and Koo [9] find that while consumer-oriented agricultural exports are sensitive to exchange rates in the short and the long run, bulk exports are relatively insensitive, in both short and long run; the effect of importers' income on exports in all three categories is unambiguous. Shane, Roe and Somwaru [8] also find that exports of red meats, poultry, fresh fruits and vegetables (high value products) have higher income elasticity than exports of bulk commodities. In contrast, Cooke et al. [2] find that while U.S. bulk exports are especially sensitive to the strength of the U.S. dollar, consumer-oriented agricultural exports are not; the authors also find that a prolonged period of dollar strengthening produces larger declines in U.S. exports of crops than meat, and that these losses translate into an overall loss in U.S. export market shares of global agricultural trade.

Ardeni and Freebairn [10] present an excellent summary of early works using time-series methods to examine macroeconomic linkages of U.S. agriculture. Recent empirical work drawing upon time-series methods has included autoregressive distributed lag models [11, 12], vector autoregression and vector error correction [13-20], and global vector autoregression models [21].

Interactions among variables in a macroeconomic model are far more complex than what is captured by the posited long-run equilibrium relationship alone; studying the short-run transition dynamics provides a richer understanding of the underlying structure. Even when a long-run relationship exists, Karp and Perloff [6] caution that a static model "has no predictive power outside the steady state", while Chambers and Just [22] argue that static models cannot be used to examine dynamic adjustments to dollar devaluations. A dynamic model can help understand the macroeconomic forces that determine the trajectory of effects of a strengthening dollar on agricultural exports. In addition,

\footnotetext{
${ }^{1}$ Karp and Perloff [6] and Orden [7] provide instructive summaries of exchange rate effects on agricultural trade.
}

a dynamic model can provide insights into such effects even when the existence of a structural long-run equilibrium relationship cannot be established by the data.

In this paper, we extend the Shane, Roe, and Somwaru [8] paper to examine the short- and long-run structural relationship between volume of exports, economic growth, and real exchange rate volatility, and the impact of exogenous shocks on the evolution of export volume, foreign income, and real exchange rate. Within this theoretical framework, we examine U.S. agricultural sector's international competitiveness and opportunities for export extensification. The econometric model uses the bounds test, developed by Pesaran, Shin and Smith [23], which alleviates the problem of modeling potentially cointegrated variables when there is uncertainty about the unit root properties of the underlying regressors. Using economic theory to formulate a structural export demand relationship, we use impulse response analysis and forecast error variance decomposition within an error correction model_-"an excellent framework within which it is possible to apply both the data information and the information obtainable from economic theory" [24] - to study the short-run transition dynamics of the export demand system in response to exogenous shocks.

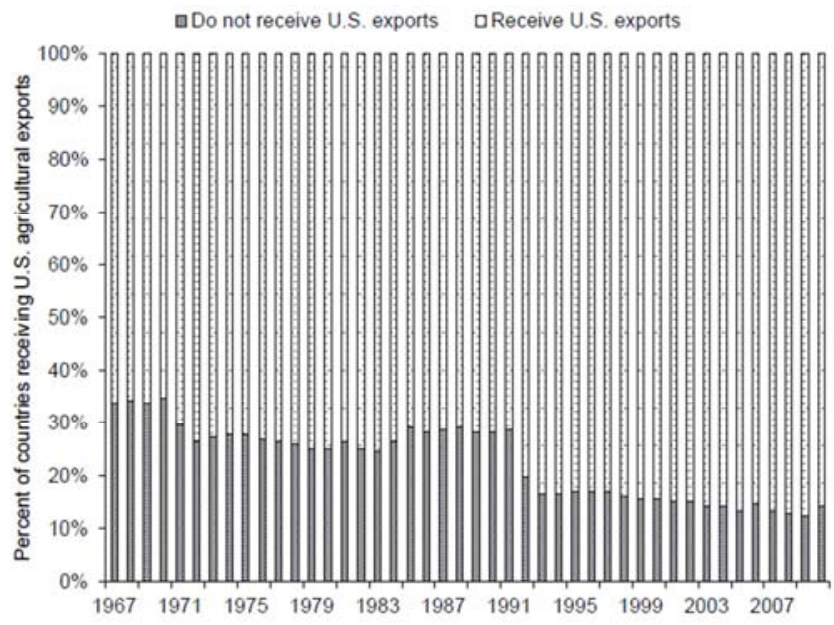

Figure 1. Share of countries in sample importing U.S. Agricultural Products.

Our paper makes three main contributions to the extant literature. First, we provide a comprehensive analysis of the long- and short-run dynamics of U.S. agricultural export demand, using data on 21 commodities and commodity categories, for the period 1967-2010. Second, our paper shows that disequilibrating shocks to U.S. agricultural exports are rather costly to low-income countries with relatively high export shares for food, resulting in a speedy convergence to pre-shock long-run equilibrium levels of imports. Third, we highlight the importance of including the long-run relationship when modeling the short-run dynamics [25], which has not received sufficient attention in the literature. Our framework begins with an explicit statement of the underlying macroeconomic theory; a priori identification restrictions used to draw structural inference, therefore, relate to the long-run properties of the macroeconomic variables, thus avoiding 
Sims's critique of the ad-hoc use of 'incredible identifying restrictions' [26]. To our knowledge, our paper is the first to comprehensively estimate macroeconomic linkages of U.S agricultural exports, simultaneously across a number of agricultural products, importing countries, over a period of five decades.

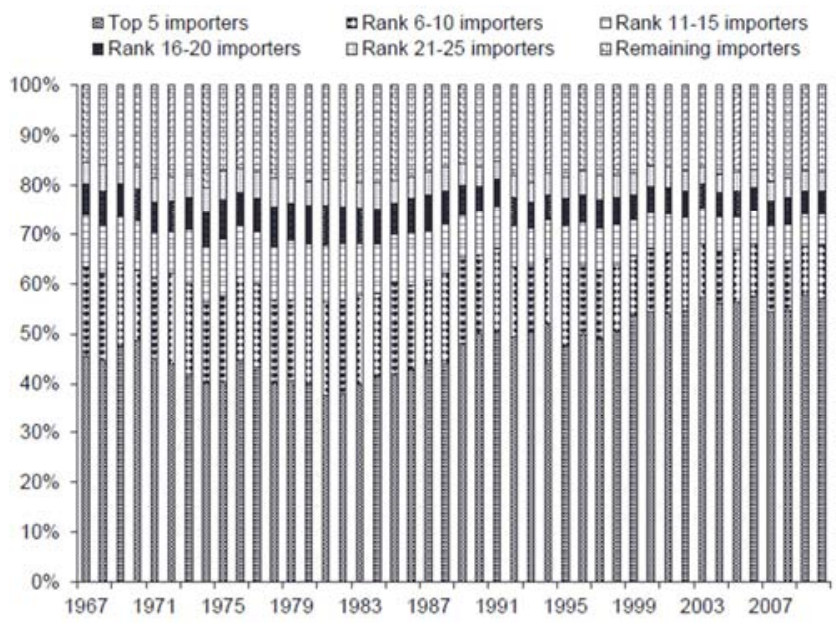

Figure 2. Share of U.S. agricultural exports accruing to top 25 importers.

In the following sections, descriptive evidence from available data is presented to motivate the argument, followed by the theoretical and econometric framework, a discussion of the long-run export demand elasticities and short-run dynamics of the export demand model.

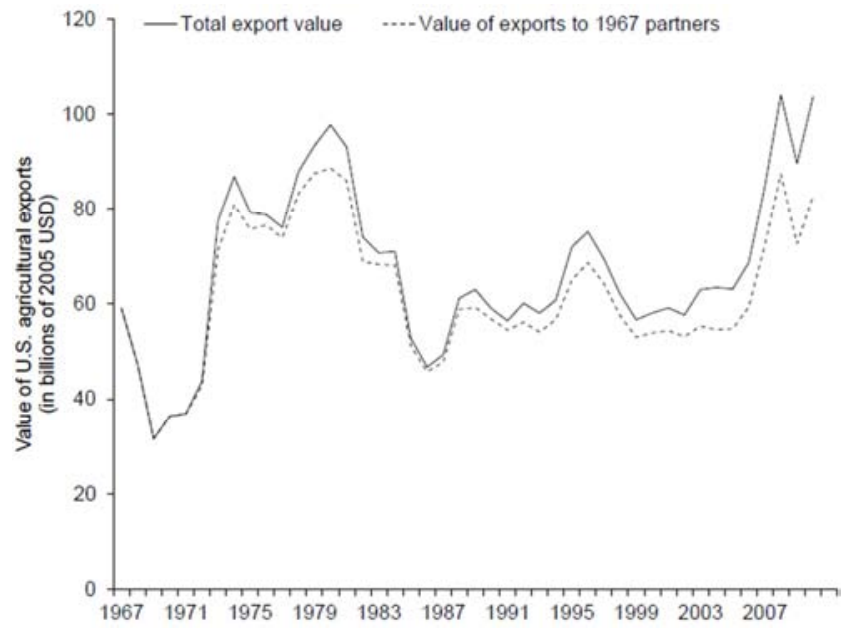

Figure 3. Value of exports to all countries \& to those that imported in 1967.

\section{Descriptive Evidence}

We use annual data from 1967 to 2010 on quantity and value of U.S. agricultural exports, provided by the Foreign Agriculture Service, United States Department of Agriculture [27]. The full sample includes exports of 26 agricultural commodities, and five commodity groups (bulk commodities, grains, high-value intermediate goods, high-value processed goods, and produce and horticultural goods); we also examine the total value of U.S. agricultural exports. The trade-adjusted
GDP series is constructed from the World Bank's World Development Indicators data on export of goods and services [28]. Finally, commodity-specific real effective exchange rate series are from the Economic Research Service, United States Department of Agriculture [29].

Figure 1 shows that U.S. agricultural exports reached 20\% more countries in 2010 than in 1967, indicating expansion of agricultural exports along the extensive margin. However, inspection of the intensive margin of U.S. agricultural exports reveals that for every year in the sample, 25 countries have accounted for at least $80 \%$ of all agricultural exports (Figure 2). While the countries in the top-25 list have changed remarkably, U.S. agricultural exports have remained concentrated in a handful of countries. In fact, as figure 3 shows, expansion of agricultural trade along the extensive margin has not been a major factor in the growth of U.S. agricultural exports.

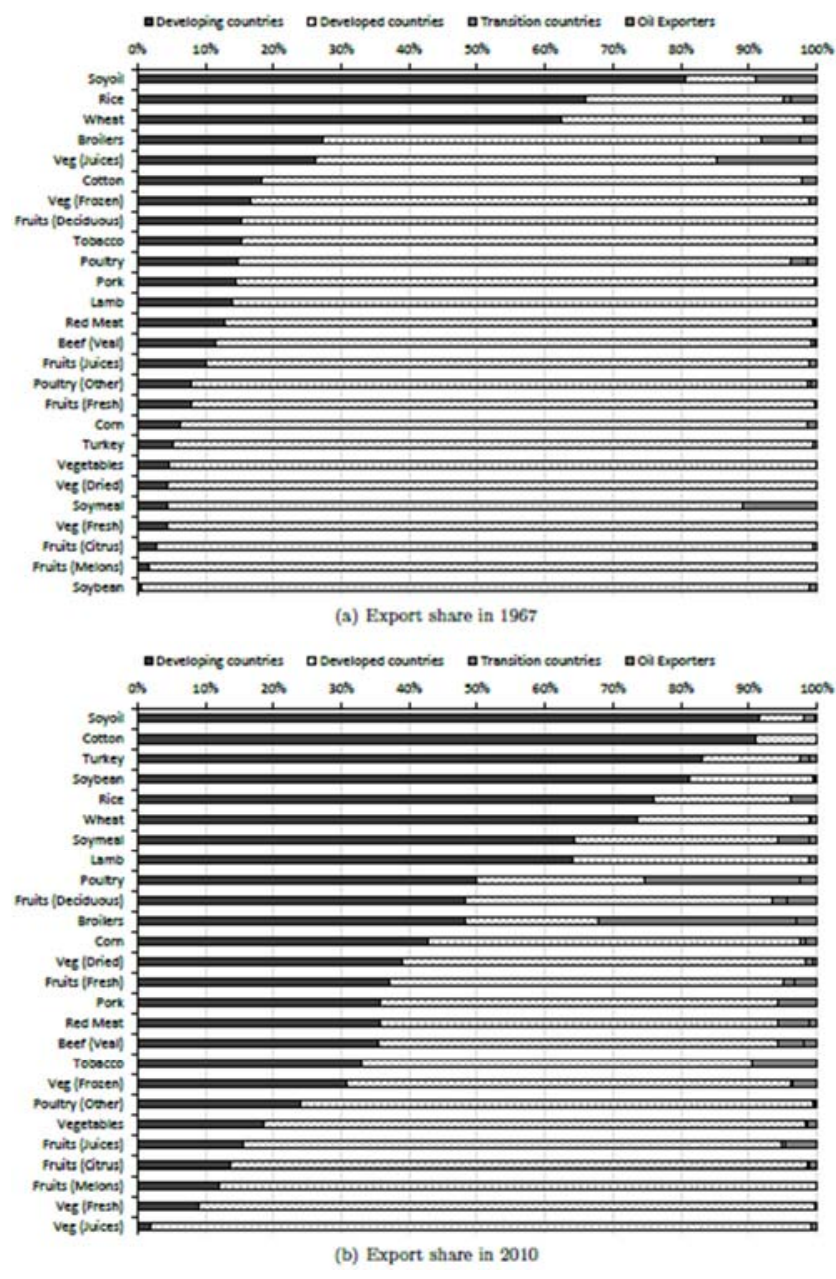

Figure 4. Distribution of U.S. agricultural exports - 1967 and 2010.

The evolution of U.S. agricultural exports can be further refined by classifying importers as developing, transition, developed, or oil-exporting countries. Figure 4 shows the evolution of U.S. agricultural exports from 1967 to 2010 across different commodities. Developing countries remain major importers of bulk exports, whereas horticulture and produce exports remain highly concentrated, with at least $80 \%$ 
of fruits and vegetable exports accruing to developed countries. This concentration of exports notwithstanding, developing countries' imports of meat and meat products (pork, red meat, lamb, poultry, and turkey) show major increases over the 1967-2010 period. Developing country markets are, thus, increasingly important for U.S. agricultural exports of meat and bulk commodities.

Additionally, the evolution of trade-weighted index of per capita income of importing countries (Figure 5) indicates that developed countries with high per-capita incomes are associated with imports of high-value processed commodities, while low- and middle-income developing countries primarily import low-value grains and bulk commodities. The implication is that economic growth in developing countries will create new possibilities for expansion of U.S. exports of higher value-added commodities to heretofore untapped markets.

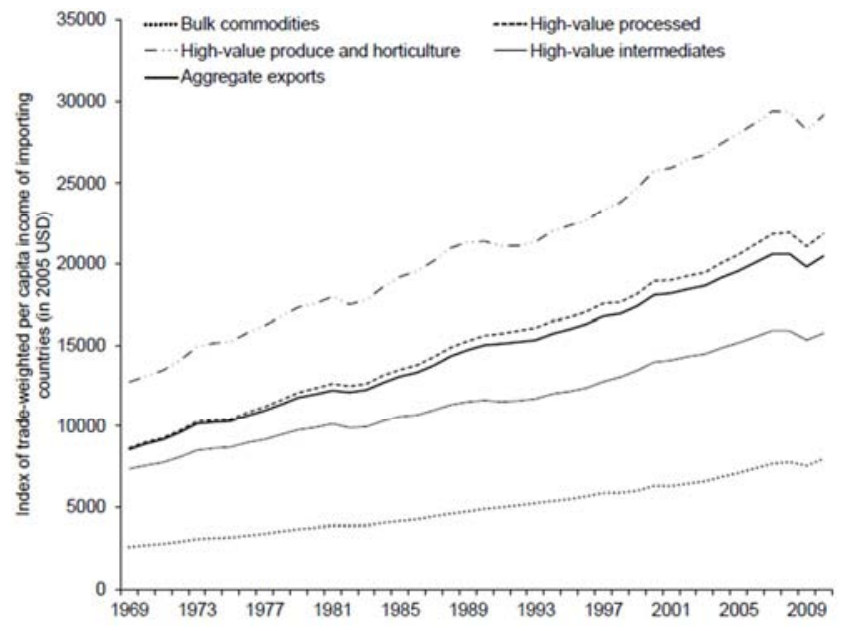

Figure 5. Commodity trade-weighted index of importers' per capita income.

\section{Theoretical Framework}

The analytical model follows that of Shane, Roe and Somwaru [8], which is, in turn, derived from Senhadji and Montenegro [30]. Starting from a two-country world-a home country (exporter) and a foreign country (importer) - the authors derive the export demand function as:

$$
\log \left(x_{t}\right)=c_{0}+c_{1} \log \left(g d p_{t}^{*}-x_{t}\right)-c_{2} \log \left(p_{t}\right)
$$

Here, $c_{0}, c_{1}$, and $c_{2}$ are functions of the curvature parameters of the utility function; $g d p_{t}^{*}$ is the importing country's endowment of the domestically produced good; $x_{t}^{*}$ is the quantity of domestic good exported to the home country; $p_{t}$ is the real exchange rate between the two countries' currencies. Thus, foreign demand for a country's exports is a function of the importer's trade-adjusted GDP $\left(g d p_{t}^{*}-x_{t}^{*}\right)$, and the relative price of the imported good, or the exchange rate $\left(p_{t}\right)$.

To implement the above export demand function in a multi-country, multi-commodity framework, we construct commodity-specific indexes for importers' trade-adjusted GDP and real exchange rate. The aggregate foreign demand for home country's exports of the $i$ 'th commodity $(i=1,2, \ldots N)$ can be expressed as in (2), where the commodity-specific weights, $\omega_{i, t}^{k}$ are defined as the share of home country's exports of the $i$ 'th commodity accruing to the $k^{\prime}$ th importing country $(k=1,2, \ldots, K)$.

$$
\begin{aligned}
\log \left(x_{i, t}\right)= & \mu_{i}+\delta_{i} \log \left[\sum_{k=1}^{K} \omega_{i, t}^{k}\left(g d p_{t}^{k *}-x_{t}^{k *}\right)\right]+ \\
& \gamma_{i} \log \left[\sum_{k=1}^{K} \omega_{i, t}^{k}\left(\operatorname{rer}_{t}^{k *}\right)\right]+\varepsilon_{i, t}
\end{aligned}
$$

Trade-weighted indices are an average measure, where each country is weighted by its importance in trade. Countries accounting for the largest share of U.S. agricultural exports varies by commodities. For instance, the five countries with the largest shares (average 2003-05) of U.S. bulk commodity exports are China (29.2\%), Turkey (12.5\$), Mexico (12.2\%), Indonesia (6.6\%), and Thailand (4.5\%). In contrast, the largest importers of U.S. high-value processed commodity exports are Mexico (20.7\%), Canada (17.1\%), Japan (13.3\%), Hong Kong (9.9\%), and the Netherlands (6.2\%). Evolution of broad macroeconomic series varies substantially across the two sets of countries. The advantage of using trade-weighted indices ${ }^{2}$ is that these variations across commodities are embodied in commodity-trade weighted indices of GDP and exchange rate [29].

Finally, using $X_{i, t}, G D P_{i, t}^{*}$, and $R E R_{i, t}$ to denote, respectively, aggregate exports of commodity $i$, and commodity-export weighted indexes of importers' trade-adjusted GDP and real exchange rate to simplify notation, the structural export demand equation has the form:

$$
X_{i, t}=\mu_{i}+\delta_{i} G D P_{i, t}^{*}+\gamma_{i} R E R_{i, t}+\varepsilon_{i, t}
$$

Equation (3) is the commodity-specific structural export demand equation for home country's exports: it represents the long-run relationship underlying the movements in exports, foreign incomes and real exchange rates.

\section{Econometric Model}

The principal econometric steps consist of: first, establishing the order of integration of variables in the export demand equation; second, selecting an appropriate error correction specification of export demand that passes model diagnostic tests (serial correlation, normally distributed errors, dynamic stability); third, testing for the presence of a long-run relationship underlying the core variables; and, finally, conditional on the null of no long-run relationship being rejected, estimating parameters of the export demand model and examining short-run dynamics.

\subsection{Unit Root Properties of the Variables}

Because standard asymptotic distribution theory does not apply to estimation procedures with non-stationary data, the first task is to establish the order of integration of variables in

\footnotetext{
2 We construct a three-year moving average sequence of country export shares to reduce the impact of year-to-year volatility on trade-weights [31]. Further, we use a fixed weight scheme, using the average 2003-05 share of U.S. exports to construct the commodity trade weighted indices of foreign GDP and exchange rate.
} 
the export demand equation. It is often difficult to distinguish between borderline stationary, trend-stationary and difference-stationary processes. Selecting the appropriate method for eliminating the trend is tricky: de-trending a difference stationary process does not eliminate the stochastic portion of the trend from the series, and differencing a trend stationary process unwittingly introduces a non-invertible unit root component to the series [32].

We use the generalized least squares version of the popular augmented Dickey-Fuller (ADF) test of non-stationarity. The null hypothesis is that the series has a unit root. The Dickey-Fuller generalized least squares (DF-GLS) test performs considerably better in small samples and has greater power than the ADF test, particularly in the presence of an unknown mean or trend. We also apply the Kwiatkowski, Phillips, Schmidt, and Shin [33], or the KPSS test of stationarity, which is a more conservative testing strategy because the hypothesis of interest is the alternate hypothesis. Failure to reject the null hypothesis of the KPSS test indicates that the evidence in favor of a unit root is insufficient. If the DF-GLS test simultaneously suggests the presence of a unit root, it is prudent to go with the verdict of the more conservative test and conclude that the series does not possess a unit root. Clearly, if the verdicts of the two tests concur, the integration properties of the variables can be determined conclusively.

\subsection{A Long-Run Model of Export Demand}

To keep notation simple, commodity subscripts are suppressed. Assuming that the structural export demand equation (2) can be well-approximated by a log-linear vector autoregression (VAR) model, let $y_{t}=\left(X_{t}, G D P_{t}^{*}, R E R_{t}\right)^{\prime}$ be the vector of endogenous variables: quantity exported by the home country, index of importing countries' trade-adjusted GDP, and index of importing countries' trade-weighted real exchange rate, respectively, all expressed in natural logs. The unrestricted vector error correction model has the following representation:

$$
\Delta y_{t}=b+\theta t+\Pi y_{t-1}+\sum_{i=1}^{p-1} \Gamma_{i} \Delta y_{t-i}+u_{t}
$$

where $y_{t}=\left(X_{t}, G D P_{t}^{*}, R E R_{t}\right)^{\prime}$ is the vector of endogenous variables, $\Pi$ and $\Gamma_{i}$ are matrices of long-run elasticities and $i$ 'th-lag short-run response parameters, respectively; $\Delta$ is the difference operator, $b=\left(b_{x}, b_{g}, b_{r}\right)^{\prime}$ is a vector of intercepts; $\theta=\left(\theta_{x}, \theta_{g}, \theta_{r}\right)^{\prime}$ is a vector of trend coefficients; $p$ is the number of lagged differences of the endogenous variables; and $u_{t}=\left(u_{x, t}, u_{g, t}, u_{r, t}\right)^{\prime}$ is a vector of serially-uncorrelated zero-mean stationary errors. Thus, the VECM form of the export demand equation can be expressed as:

$$
\Delta X_{t}=b_{x}+\theta_{x} t+\pi_{x, x} X_{t-1}+\pi_{x, g} G D P_{t-1}^{*}+\pi_{x, r} R E R_{t-1}+\sum_{i=1}^{p-1} \gamma_{x, x ; i} \Delta X_{t-i}+\sum_{i=1}^{p-1} \gamma_{x, g ; i} \Delta G D P_{t-i}^{*}+\sum_{i=1}^{p-1} \gamma_{x, r ; i} \Delta R E R_{t-i}+u_{x, t}
$$

The Akaike Information Criterion [34], the Schwarz-Bayesian Information Criterion [35], and the Hannan-Quinn Information Criterion [36] (AIC, SBC, and HQIC respectively) are used to determine the optimal number of lags, $p$, in the VECM. The chosen model should satisfy two additional requirements: first, the error terms, $u_{t}$ in (5) must be serially independent. We use Durbin's Lagrange multiplier test [37] to test for presence of residual serial correlation. Due to the autoregressive structure, interpretation of the VECM requires the model to be dynamically stable. This is the second requirement. Dynamic stability ensures that the cumulative effect of a shock does not cause a series to have an explosive time-path: this is critical if the model is used for forecasting.

If the data accepts the structural model, we can extract the long-run GDP and exchange rate elasticities from the conditional VECM (eq. 5). The long-run relationship between exports, importers' trade-adjusted income, and real exchange rate can then be expressed as:

$$
X_{t}=\alpha_{0}+\xi_{x, g d p^{*}}(\text { Foreign GDP })+\xi_{x, R E R}(\text { Real exchange rate })+v_{t}
$$

where $\xi_{x, g d p^{*}}$ is the long-run multiplier between home country's exports and foreign countries' trade-adjusted GDP, and $\xi_{x, R E R}$ is the long-run multiplier between home country's exports and real exchange rate.

Economic interpretation of the estimated elasticities is somewhat tricky. For example, interpreting $\xi_{x, g d p^{*}}$ as the long-run effect of a unit increase in foreign countries' GDP on home country's exports ignores the dynamic effects captured by, for example, the lagged differences of the real exchange

$$
\Delta X_{t}=b_{x}+\theta_{x} t+\psi \hat{v}_{t-1}+\sum_{i=1}^{p-1} \gamma_{x, x ; i} \Delta X_{t-i}+\sum_{i=1}^{p-1} \gamma_{x, g ; i} \Delta G D P_{t-i}^{*}+\sum_{i=1}^{p-1} \gamma_{x, r ; i} \Delta R E R_{t-i}+u_{x, t}
$$

where the error correction term, $\hat{v}_{t-1}$, is the one-period lagged disequilibrium error, computed from the long-run export demand equation as:

$$
\hat{v}_{t}=X_{t}-\hat{\alpha}_{0}-\hat{\xi}_{x, g d p^{*}}\left(G D P_{t}\right)-\hat{\xi}_{x, r e r}\left(R E R_{t}\right)
$$

rate. An understanding of interrelationships among the variables in the VECM (5) requires examination of the short-run dynamics of the system, to which we now turn.

\subsection{Short-Run Dynamics}

To examine the short run transition dynamics of fluctuations in foreign GDP and exchange rate, we formulate a restricted VECM as able is as follows:
This specification of the short-run behavior ensures that long-run predictions of export demand and deviations of actual exports from the level predicted by the long-run relationship are embodied in the error correction form of the structural export demand equation. 


\subsubsection{Speed of Adjustment}

The coefficient on the error-correction term, $\psi$, is the adjustment parameter. It measures the speed at which deviations from long-run equilibrium are corrected to restore long-run equilibrium. For example, $\psi=0.3$ implies that roughly $30 \%$ of the disequilibrium between actual and predicted exports is corrected within one time period. The requirement of dynamic stability implies that the value of the adjustment parameter must be negative. A negative value of $\psi$ implies that if, for example, actual exports exceed the predicted long-run equilibrium level, exports will subsequently grow slower than the long-run rate to restore the level of exports to the long-run mean. This is the 'error correction' process: when the variables are out of long-run equilibrium, economic forces, by adjusting upwards (in response to negative disequilibrium error) or downwards (in response to positive disequilibrium error), act to restore the long-run equilibrium.

\subsubsection{Impulse Response Function}

The dynamic nature of this system allows us to conduct impulse response analysis to trace the effect of an exogenous shock to one variable on other variables [38]. For example, we can trace the impact of a one standard deviation disturbance in commodity-trade weighted real exchange rates on the evolution of U.S. agricultural exports of a particular commodity. Consider an n-dimensional mean-centered VAR(p) model $x_{t}=\mu+\sum_{i=1}^{p} A_{i} x_{t-i}+\varepsilon_{\mathrm{t}}$, where $\mu$ is a vector of means, and $\varepsilon_{t}$ is a vector of jointly-determined, serially-uncorrelated white noise disturbances with a multivariate normal distribution: $\varepsilon_{\mathrm{t}} \sim \operatorname{MVN}(0, \Sigma)$. If $x_{t}$ is stationary, it has an infinite moving average representation $x_{t}=\mu+\sum_{i=0}^{\infty} \phi_{i} \varepsilon_{\mathrm{t}-\mathrm{i}}$. The $\phi_{i}$ represents the simple impulse response function (IRF): the element $\phi_{j k}(i)$ of the $\phi_{i}$ matrix measures the impact of a one-time shock to $\varepsilon_{k}$ on the evolution of $\varepsilon_{j}$ after $\mathrm{i}$ periods, ceteris paribus. In addition, $\phi_{j k}(0)$ are the impact multipliers, which measure the instantaneous impact of a one-unit change in $\varepsilon_{\mathrm{zt}}$ on $y_{t}$.

However, because of contemporaneous correlation among the variables, shocks to one variable may be accompanied by shocks to (several) other variables. Therefore, IRFs derived from reduced-form disturbances are not amenable to structural interpretation and are helpful only for short-term forecasts. Economically meaningful inference about the underlying structure requires identifying restrictions on parameters. The strength of our structural cointegrating VAR framework is that a priori restrictions used to identify structural shocks are well-defined and relate to the long-run properties of the macroeconomic variables. This strategy avoids Sims's critique [26] of the ad-hoc use of incredible identifying restrictions.

We assume that the $j$-th country's foreign GDP and real exchange rate are long-run forcing for U.S. agricultural exports [23]. To illustrate, assume that the long run structural VAR form of the export demand system is: $y_{t}=A e_{t}$, where $y_{t}=\left\{X_{t}, G D P_{t}^{*}, R E R_{t}\right\}$ is the vector of endogenous variables, $e_{t}$ is a vector of independently and identically distributed disturbances, and $A$ is a $3 \times 3$ matrix. With three endogenous variables, 3 restrictions are needed to identify structural shocks. We adopt the restriction that unexpected changes in U.S. exports have no long-run effects on changes in foreign GDP or real exchange rate. In addition, we assume that the long-run level of exchange rates is not affected by disturbances in foreign GDP: heuristically, exchange rates are more likely to be determined by trade, quantitative easing, domestic and international monetary policies than by the level of GDP. Thus, the implied $A$ matrix is:

$$
\left(\begin{array}{ccc}
a_{11} & a_{12} & a_{13} \\
0 & a_{22} & a_{23} \\
0 & 0 & a_{33}
\end{array}\right)
$$

\subsubsection{Forecast Error Variance Decomposition}

Forecast error variance decomposition (FEVD) measures the proportion of the movement in one endogenous variable due to (orthogonalized) shocks to itself or to other endogenous variables. In the context of the $\operatorname{VAR}(p)$ model (equation 8), the error of the n-step-ahead forecast is

$$
x_{t+n}-E_{t}\left(x_{t+n}\right)=\sum_{i=0}^{n-1} \phi_{i} \varepsilon_{\mathrm{t}+\mathrm{n}-\mathrm{i}}
$$

where $x_{t+n}$ is the value observed at time $t+n$ and $E_{t}\left(x_{t+n}\right)$ is the $n$-step-ahead predicted value for $x_{t+n}$ that was made at time $t$ [39]. Variance decomposition is the decomposition of the $n$-step-ahead forecast error variance into proportions attributable to shocks to $\left\{\varepsilon_{t}\right\}$ sequence. Thus, the fraction of total forecast error variance in U.S. exports $\left(X_{t}\right)$ that is attributable to shocks to importers' trade-adjusted GDP is:

$$
\frac{\sigma_{g d p}^{2}\left[\phi_{12}(0)^{2}+\phi_{12}(1)^{2}+\cdots+\phi_{12}(n-1)^{2}\right]}{\sigma_{\chi}(n)^{2}}
$$

Causal interpretation of variance decomposition also requires identifying restrictions to identify structural shocks from the reduced form model. We use the same exclusion restrictions as with the IRF, and report confidence intervals generated from a bootstrap procedure using 1000 replications.

\section{Results}

To allow comparison of regression estimates across models with varying lag structures, we begin our analysis with the sample from 1971 to 2010 , i.e., 40 observations. The lag order of the underlying VAR should be sufficient to remove residual serial correlation without sacrificing too many degrees of freedom due to over-parametrization. One rule of thumb is to start with the maximum lag order $p$, such that $p=\sqrt[4]{T}$, where $T$ is the sample size [40]. Having 44 observations (1967 $2010)$, our analysis begins with a maximum lag length of $3(\approx$ $\sqrt[4]{44})$. The first observation is used to construct first differences of the variables, the next three to construct the lagged series, leaving a uniform sample with 40 observations.

\subsection{Unit Root Properties and Model Diagnostics}

The DF-GLS and KPSS unit root tests are computed for the $1970-2010$ period and are applied to the variables in levels and in first differences, both with and without a deterministic trend. In models without trend, both tests 
provide evidence in favor of the export and foreign GDP series being stationary around a constant. When a linear trend is included, the KPSS test's results diverge significantly from the DF-GLS test's results for all three core variables, and it is unclear whether the series are I(0) or I(1). From the KPSS test, however, there is no evidence in favor of the export and real exchange rate series being $\mathrm{I}(2)$. The same is true for the foreign GDP series when a linear trend in first differences is

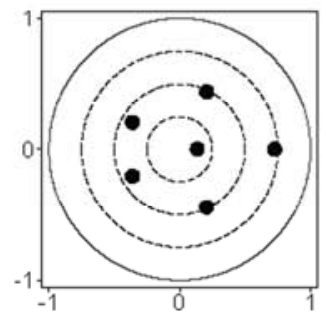

(1) Total Exp. Val.

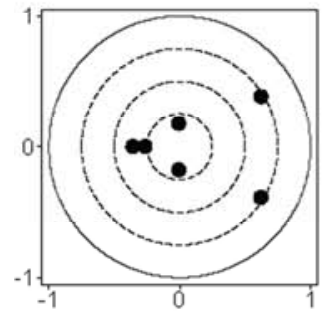

(6) Soybean

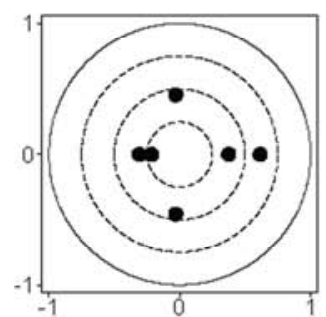

(11) Soymeal

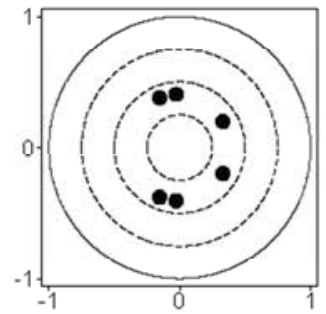

(16) Lamb

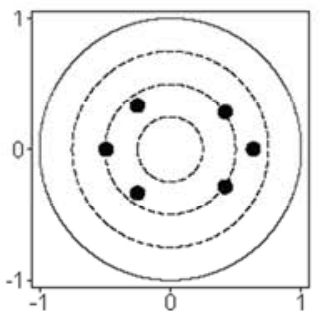

(2) Bulk Comm.

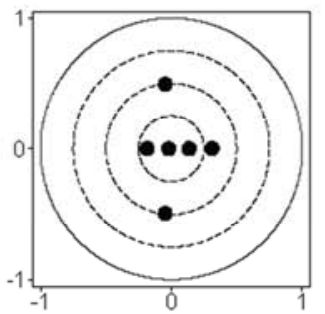

(7) Wheat

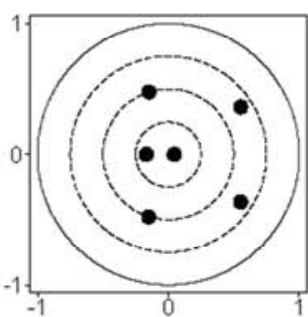

(12) Soyoil

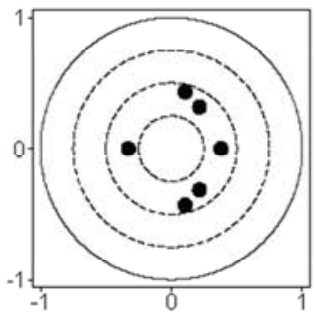

(17) Poultry

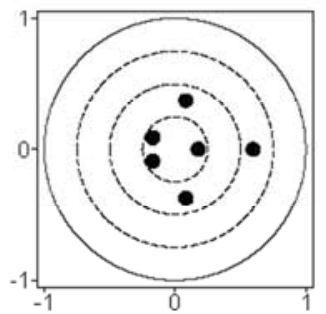

(3) Grains

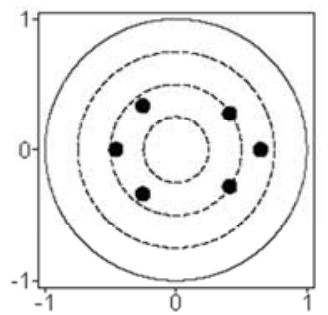

(8) Cotton

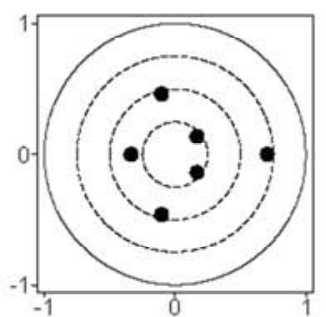

(13) High Val. Proc.

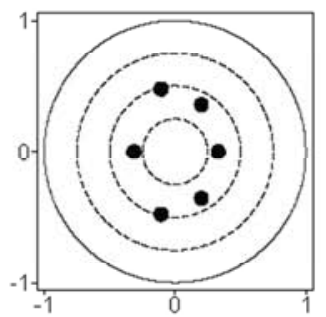

(18) Red Meat

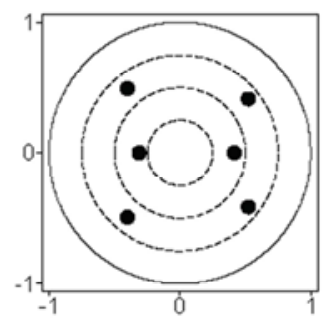

(21) Veg. (Dried)

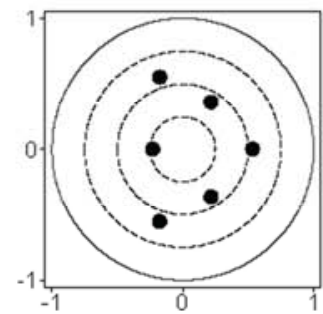

(4) Corn

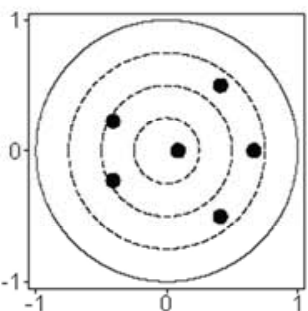

(9) Tobacco

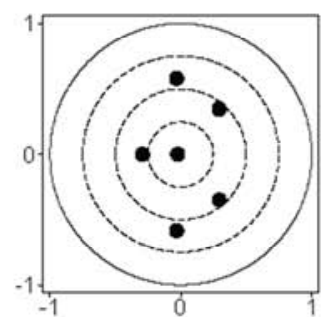

(14) Beef (Veal)

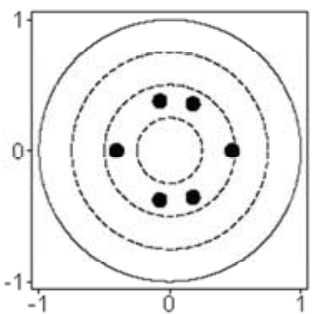

(19) Fruits (Citrus)

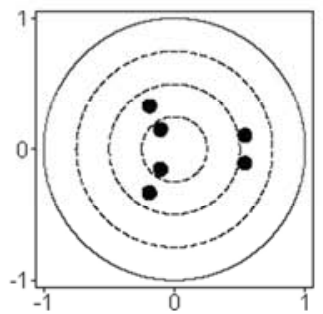

(5) Rice

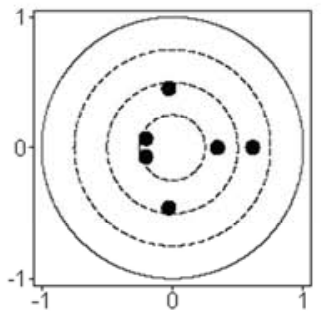

(10) High Val. Inter.

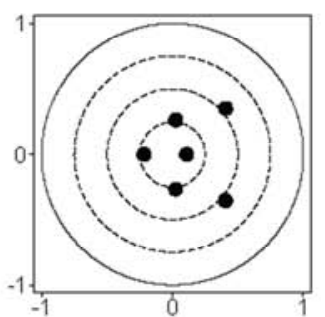

(15) Broilers

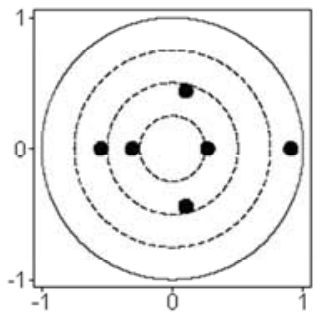

(20) Veg. (Juices) 
Diagnostic tests applied to the reduced-form error correction specifications of commodity export demand are reported in Table 1. All equations have reasonable explanatory power, with $R^{2}$ values ranging from 0.21 for beef (veal) and high-value processed exports to 0.64 for soy-oil exports. Model diagnostics are satisfactory for tests of residual serial correlation. With three exceptions, the assumption of normally distributed errors cannot be rejected. Figure 6 suggests that the error correction specifications are dynamically stable: eigenvalues for all equations are strictly within the unit circle. Lastly, actual and fitted values of the error correction specifications (Figure 7) indicate that the model does a reasonable job of capturing the underlying patterns in commodity exports; this is also true for models with low $R^{2}$ values.

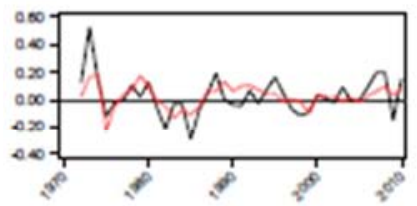

(1) Total Exp. Val.

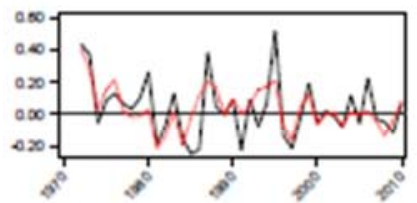

(4) Corn

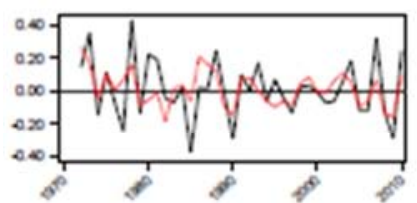

(7) Wheat

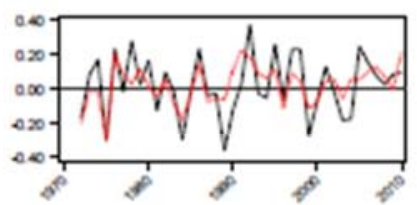

(10) High Val. Inter,

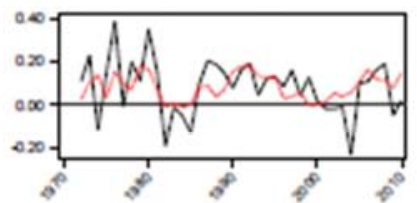

(13) High Val. Proc.

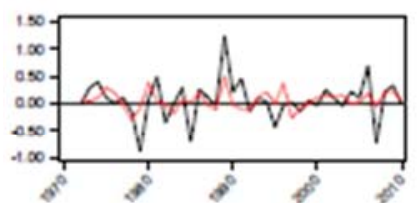

(16) Lamb

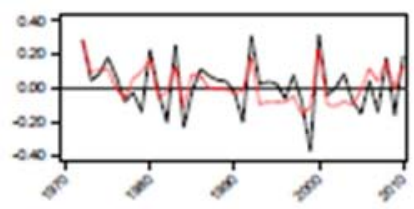

(19) Fruits (Citrus)

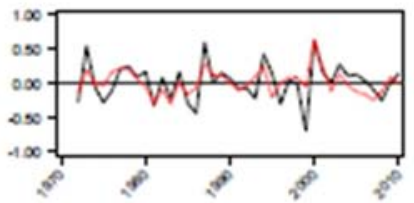

(2) Bulk Comm.

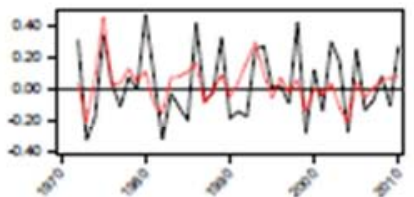

(5) Rice

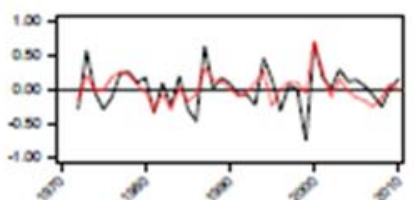

(8) Cotton

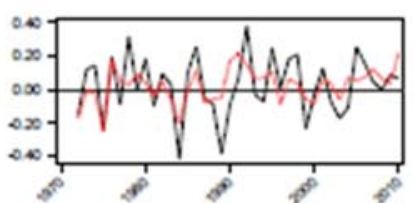

(11) Soymeal

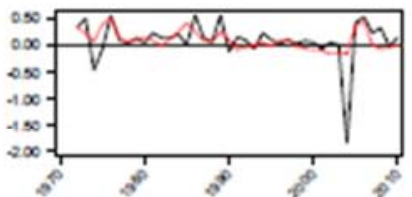

(14) Beef (Veal)

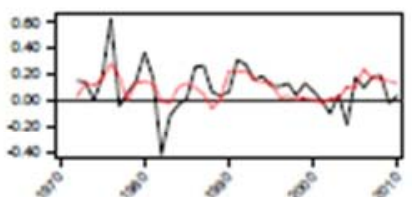

(17) Poultry

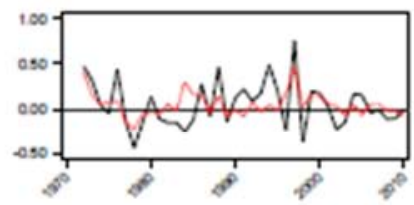

(20) Veg. (Juices)

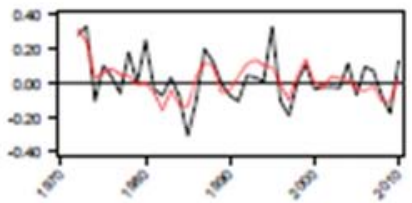

(3) Grains

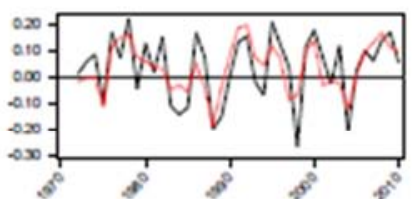

(6) Soybean

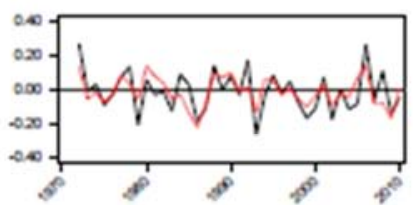

(9) Tobacco

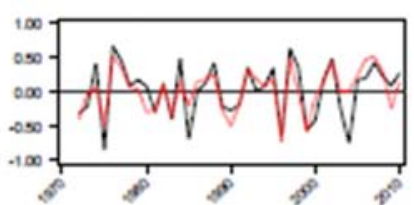

(12) Soyoil

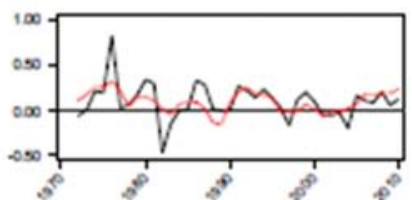

(15) Broilers

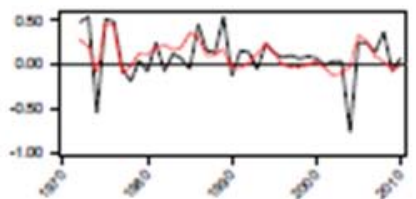

(18) Red Meat

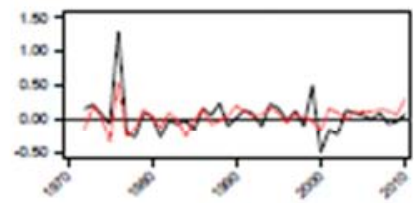

(21) Veg. (Dried)

Figure 7. Actual (black) and fitted (red) values for the export demand ECMs. 
Table 1. Model diagnostics of the export demand equations*.

\begin{tabular}{|c|c|c|c|c|c|c|}
\hline Commodity & $\mathrm{X}_{\mathrm{SC}}^{2}(\mathbf{1})$ & $\mathrm{X}_{\mathrm{SC}}^{2}(4)$ & $\mathrm{X}_{\mathrm{N}}^{2}$ & $R^{2}$ & $A I C$ & $S B C$ \\
\hline Total Export Value & 6.03 & 14.63 & $8.25^{* *}$ & 0.37 & -10.00 & -8.98 \\
\hline Bulk Commodities & 10.07 & 10.91 & 1.52 & 0.43 & -7.25 & -6.22 \\
\hline Grains & 7.72 & 6.62 & 2.60 & 0.49 & -9.08 & -8.05 \\
\hline Corn & 6.91 & 13.87 & 2.25 & 0.51 & -8.41 & -7.39 \\
\hline Rice & 4.56 & 9.59 & 4.44 & 0.31 & -8.31 & -7.29 \\
\hline Soybean & 6.62 & 10.91 & 4.43 & 0.54 & -8.97 & -7.95 \\
\hline Wheat & 6.33 & 11.46 & 3.22 & 0.35 & -8.28 & -7.25 \\
\hline Cotton & 9.83 & 11.23 & 1.37 & 0.44 & -7.07 & -6.04 \\
\hline Tobacco & 12.04 & 14.48 & 4.24 & 0.50 & -8.54 & -7.52 \\
\hline Soymeal & 9.75 & 9.30 & 2.85 & 0.34 & -8.93 & -7.91 \\
\hline Soyoil & 5.91 & 4.98 & 1.39 & 0.64 & -7.27 & -6.25 \\
\hline High Value Intermediates & 7.44 & 9.49 & 2.78 & 0.43 & -9.09 & -8.07 \\
\hline High Value Processed & 5.68 & 8.35 & 3.25 & 0.21 & -9.33 & -8.31 \\
\hline Beef (Veal) & 4.24 & 7.23 & $129.9^{* * *}$ & 0.21 & -5.43 & -4.41 \\
\hline Broilers & 7.91 & 5.76 & 1.49 & 0.32 & -7.75 & -6.73 \\
\hline Lamb & 11.10 & 5.52 & 1.39 & 0.22 & -4.57 & -3.54 \\
\hline Poultry & 7.96 & 6.77 & 1.76 & 0.26 & -7.72 & -6.69 \\
\hline Red Meat & 12.62 & 10.68 & $9.94^{* * *}$ & 0.34 & -6.97 & -5.94 \\
\hline Fruits (Citrus) & 8.83 & 10.49 & 4.46 & 0.48 & -8.58 & -7.56 \\
\hline Vegetables (Juices) & 2.38 & 7.48 & 1.52 & 0.28 & -8.22 & -7.20 \\
\hline Vegetables (Dried) & 14.36 & 11.19 & 0.95 & 0.59 & -8.07 & -7.05 \\
\hline
\end{tabular}

*Akaike's and Schwarz's Bayesian Information Criteria are denoted, respectively, by AIC and SBC. $X_{S C}^{2}(1)$ and $X_{S C}^{2}(4)$ are the statistics for the Lagrange Multiplier test of serial non-correlation against the alternate hypothesis of residual serial correlation at lags 1 and 4 , respectively. $X_{N}^{2}$ is the test statistic for the Jarque-Bera test non-normal errors. Finally, $R^{2}$ is the coefficient of multiple determination measuring goodness of fit.

\subsection{Long-Run Estimates}

Where a statistically significant long-run export demand equation exists, long-run elasticities of U.S. agricultural exports with respect to importers' trade-adjusted GDP and trade-weighted exchange rate are summarized in Table 2. Standard errors are reported in parentheses. Three observations stand out: in the long run, (i) an increase (decrease) in importing countries' trade-adjusted GDP leads to an increase in U.S. agricultural exports; (ii) a real appreciation (depreciation) of the U.S. dollar results in a decline (increase) in U.S. agricultural exports; and (iii) exports of high-value processed agricultural products are more sensitive to changes in foreign income and exchange rate fluctuations than exports of low-value grains and bulk commodities.

Table 2. Long-run foreign income and exchange rate elasticities*.

\begin{tabular}{|c|c|c|c|c|}
\hline Commodity & Foreign GDP & Exchange Rate & Intercept & Trend \\
\hline Total Export Value & $-0.439(1.029)$ & $-3.404^{* * *}(0.658)$ & 35.56 & $0.030(0.030)$ \\
\hline Bulk Commodities & $0.779^{* * *}(0.128)$ & $-0.842^{*}(0.377)$ & 20.47 & \\
\hline Grains & $0.236(0.139)$ & $-0.332(0.369)$ & 18.05 & \\
\hline Corn & $0.353^{*}(0.163)$ & $0.114(0.507)$ & 15.64 & \\
\hline Rice & $0.697^{* * *}(0.208)$ & $-0.694(0.494)$ & 13.67 & \\
\hline Soybean & $-1.084(0.901)$ & $-1.211^{* * *}(0.280)$ & -38.14 & $0.078^{*}(0.036)$ \\
\hline Wheat & $0.138(0.323)$ & $0.938(0.590)$ & 11.86 & \\
\hline Cotton & $0.785^{* * *}(0.130)$ & $-0.861^{*}(0.378)$ & 20.50 & \\
\hline Tobacco & $0.645^{* *}(0.233)$ & $-0.600^{* * *}(0.124)$ & 39.41 & $-0.030^{* * *}(0.004)$ \\
\hline Soymeal & $1.849^{* * *}(0.313)$ & $-1.889^{*}(0.755)$ & 12.72 & \\
\hline Soyoil & $0.320(0.295)$ & $-1.081(0.738)$ & 16.47 & \\
\hline High Value Intermediates & $1.502^{* * *}(0.232)$ & $-1.791^{* *}(0.645)$ & 14.56 & \\
\hline High Value Processed & $3.319^{* * *}(0.256)$ & $-3.487^{* * *}(0.879)$ & 9.42 & \\
\hline Beef (Veal) & $0.596(0.962)$ & $1.984(1.677)$ & 0.33 & \\
\hline Broilers & $1.979^{* * *}(0.388)$ & $-2.547^{* *}(0.855)$ & 13.89 & \\
\hline Lamb & $2.714^{* * *}(0.197)$ & $-3.013^{* * *}(0.337)$ & 5.82 & \\
\hline Poultry & $2.659^{* * *}(0.249)$ & $-2.429^{* *}(0.782)$ & 9.79 & \\
\hline Red Meat & $2.524^{* * *}(0.321)$ & $0.396(0.882)$ & -6.63 & \\
\hline Fruits (Citrus) & $0.140(0.127)$ & $-0.473(0.370)$ & 15.01 & \\
\hline Vegetables (Juices) & $-11.82^{* * *}(2.207)$ & $-3.605^{*}(1.629)$ & -281.9 & $0.313^{* * *}(0.053)$ \\
\hline Vegetables (Dried) & $0.451(0.373)$ & $-2.041^{*}(0.949)$ & 18.32 & \\
\hline
\end{tabular}

${ }^{*}$ Standard errors are in parenthesis. ${ }^{* * *}, * *$, and $*$ indicate significance at the $1 \%, 5 \%$, and $10 \%$ level, respectively. Standard errors for the long-run elasticity estimates are calculated using the delta method, which uses a Taylor-series expansion to approximate the variance of the parameter. Standard errors for the intercept term are not reported because in VECMs with unrestricted intercept, the intercept in the cointegrating equation is not estimated directly. Instead, it is backed out from the estimate of a model-wide intercept; see Stata documentation for the -vec- command [39]. 
Thus, equal growth across all importing countries leads to a smaller increase in U.S. exports of bulk commodities than high-value processed commodities. For example, a $10 \%$ growth in trade-adjusted GDP across all importing countries leads to a $7.8 \%$ increase in U.S. exports of bulk commodities compared to $33 \%$ increase in exports of high-value processed commodities ${ }^{3}$. Similarly, real appreciation of the dollar leads to a more than proportionate decline in U.S. exports of processed meats and vegetables relative to bulk exports. Specifically, a $10 \%$ increase in the value of the trade-weighted exchange rate (i.e., an appreciation of the U.S dollar) reduces bulk exports by $8.4 \%$ compared to a whopping $35 \%$ decline in high-value processed food exports.

The difference in the magnitude of GDP and exchange rate elasticities between bulk and processed commodities is not surprising. Engel's law contends that the budget share of necessities declines as incomes rise. At low levels of income grains comprise a large share of an average household's diet: in a survey of 1529 rural households in Bihar in India, Christian [41] finds that households spent 33\% of their food budget on the staple food (rice, wheat, or maize); rice alone accounted for more than $25 \%$ of food expenditure. Demand for 'necessities' is relatively invariant to income and price shocks. Higher income allows for diversification of diet to include more processed meats, fruits and vegetables. Magnitude of the exchange rate elasticity increases (in absolute terms) as we move away from primary commodities towards value-added items, with a $10 \%$ appreciation of the U.S. dollar leading to a $30 \%$ decline in U.S. lamb exports.

Foreign-income elasticities of U.S. agricultural export demand have striking empirical regularities with historical data and the literature on income-and-price elasticities. Krugman [42] suggests that countries with high-rates of growth have low income-elasticity of import demand, whereas countries with slow growth rates have high income elasticity for imports. Thus, high rates of economic growth in developing and emerging market economies explain the low long-run income elasticity of demand for U.S. bulk commodity exports [43-45]. Similarly, high income elasticity of demand for value-added processed U.S. agricultural exports is explained by the slow-growing economies of high-income developed countries.

\subsection{Short-Run Dynamics}

\subsubsection{Speed of Convergence}

The short-run dynamics of the export demand system are characterized by the reduced-form error correction specification reported in Table 3. The speed of adjustment estimates are highly statistically significant, which substantiates the existence of a stable structural export demand equation for exports of the listed commodities [46, 47]. More importantly, the high statistical significance of the error correction coefficient highlights the importance of including the long-run relationship when modeling the short-run dynamics [25]. This is one of our contributions to the literature, as the joint determination of long- and short-run dynamics has not received sufficient attention in the agricultural economics literature.

Comparison of the estimates of the speed of adjustment across commodities reveals that, on average, exports of grains and bulk commodities converge to long-run equilibrium at a faster rate than exports of high-value processed commodities. For example, more than $75 \%$ of the disequilibrium in aggregate bulk commodity exports is corrected within one year. By comparison, less than $15 \%$ of the disequilibrium in high-value processed exports is grains and bulk commodities converge to long-run equilibrium at a faster rate than exports of high-value processed commodities. For example, more than $75 \%$ of the disequilibrium in aggregate bulk commodity exports is corrected within one year. By comparison, less than $15 \%$ of the disequilibrium in high-value processed exports is corrected within one year. Thus, in response to exogenous shocks, deviations from the equilibrium level of exports predicted by the structural export demand equation are corrected at a much faster rate for grains and other bulk commodity exports than export of high value commodities.

This finding has implications for U.S. agricultural policy. Disequilibrating shocks are rather costly in low-income countries with relatively high export shares for food, resulting in a speedy convergence to pre-shock long-run equilibrium levels of imports. Pick [48] has argued that well-developed financial and commodity markets play an important role in understanding the nature of exchange rate risk in developing countries. A similar argument is presented by [31] in the context of oil exports: major oil exporters, such as Venezuela, have faster speed of convergence relative to developed countries, such as Switzerland, and the authors contend that well-developed financial markets may "act as shock absorbers," causing a "more sluggish response to shocks". The faster speed of convergence to long-run equilibrium for commodities that are mainly exported to developing countries suggests that U.S. agricultural exports may benefit not only from policies intended to increase trade with existing developing country importers (expanding exports along the intensive margin) but also from policies that aim to export agricultural commodities to hitherto unexplored emerging markets (expanding exports along the extensive margin). 


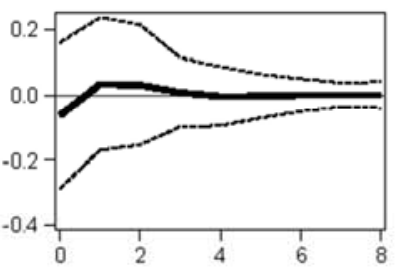

(1) Total Exp. Val.

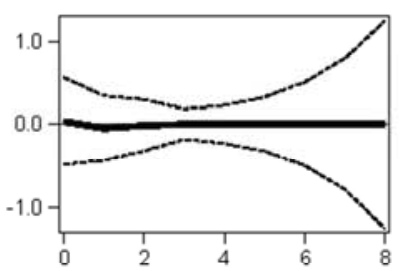

(5) Rice

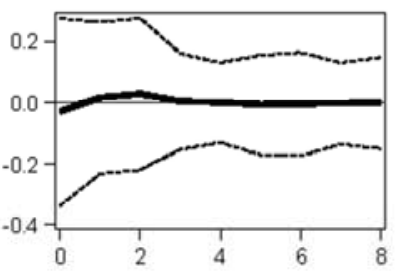

(9) Tobacco

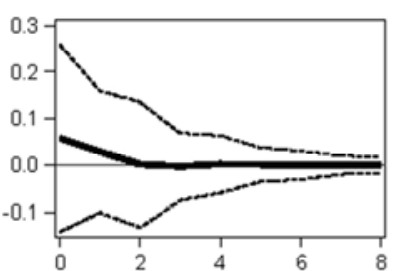

(13) High Val. Proc.

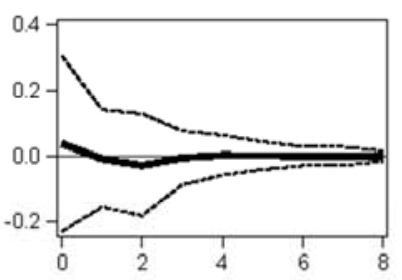

(17) Poultry

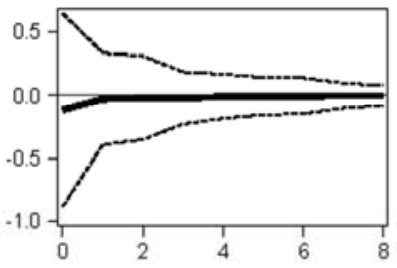

(2) Bulk Comm.

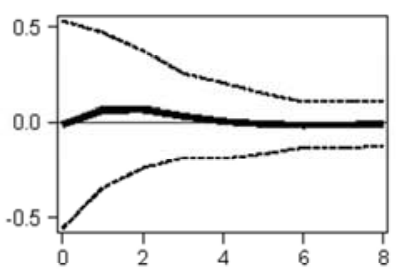

(6) Soybean

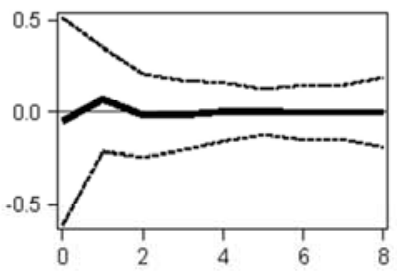

(10) High Val. Inter.

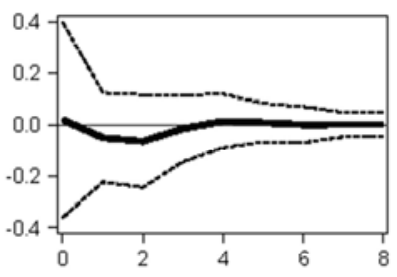

(14) Beef (Veal)

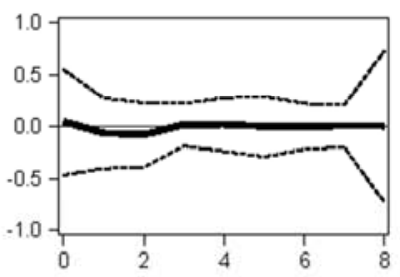

(18) Red Meat

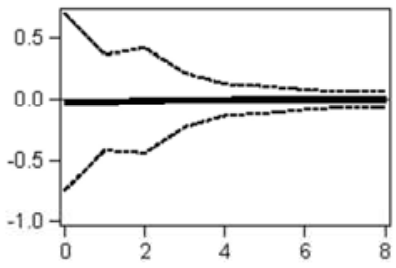

(3) Grains

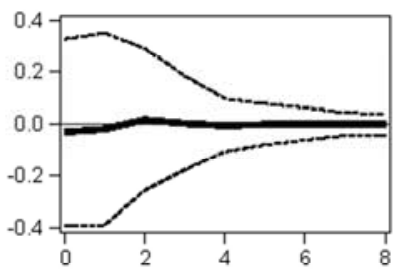

(7) Wheat

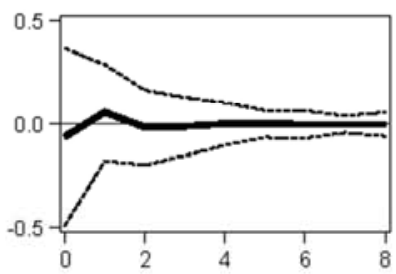

(11) Soymeal

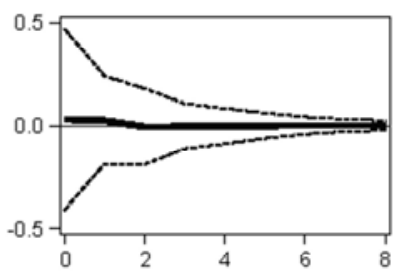

(15) Broilers

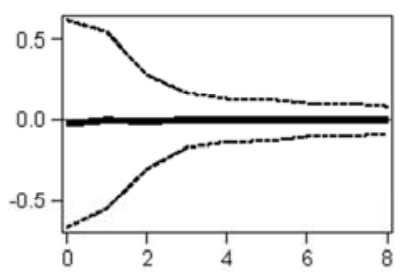

(19) Fruits (Citrus)

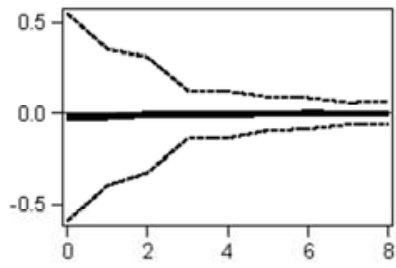

(4) Corn

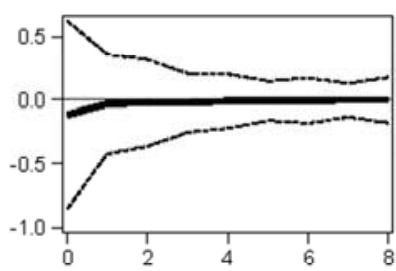

(8) Cotton

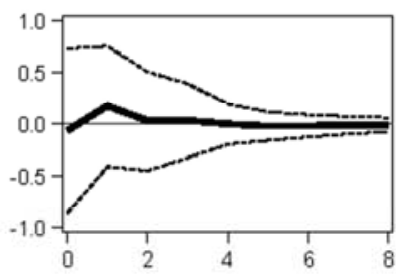

(12) Soyoil

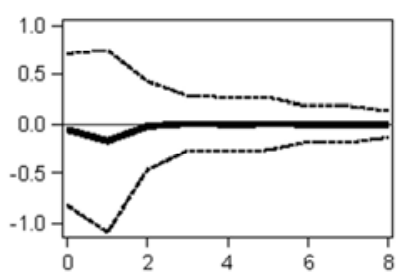

(16) Lamb

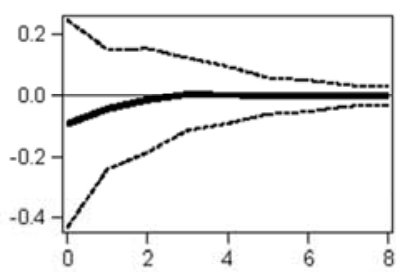

(20) Veg. (Juices)

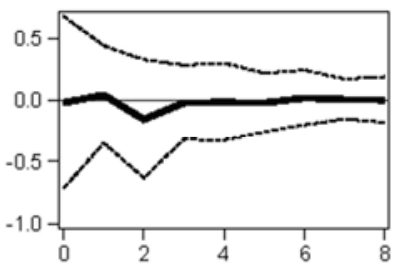

(21) Veg. (Dried)

Figure 8. Impulse response function: Importers' GDP $\rightarrow$ U.S. Agricultural Exports. 


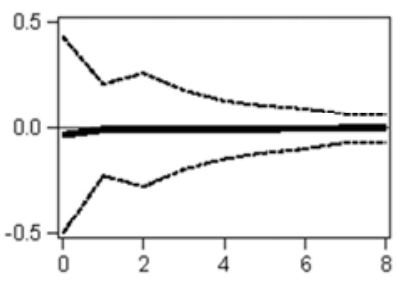

(1) Total Exp. Val.

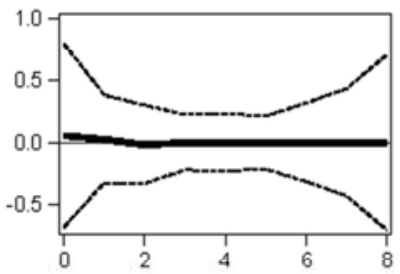

(5) Rice

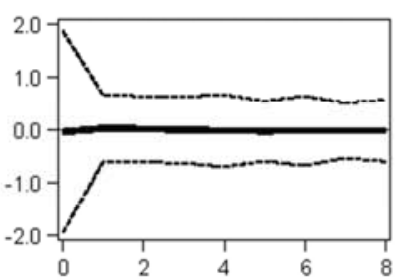

(9) Tobacco

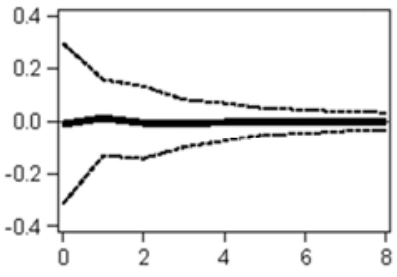

(13) High Val. Proc.

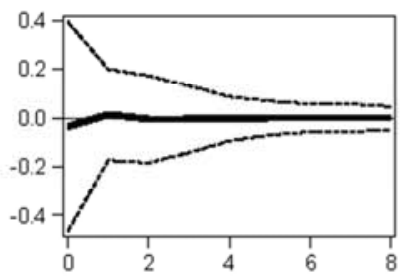

(17) Poultry

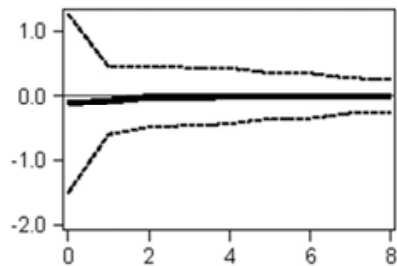

(2) Bulk Comm.

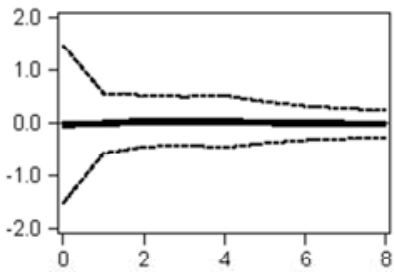

(6) Soybean

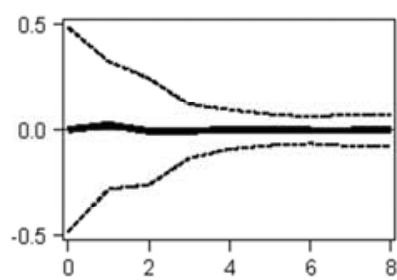

(10) High Val. Inter.

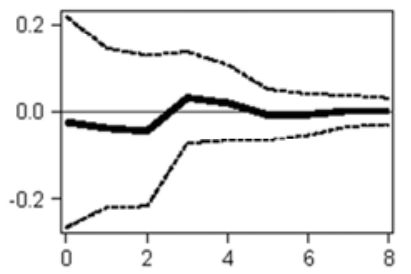

(14) Beef (Veal)

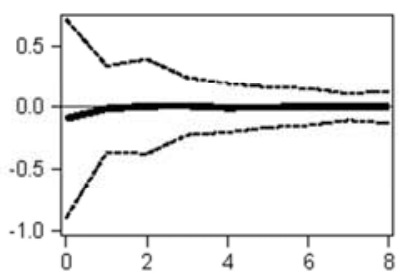

(18) Red Meat

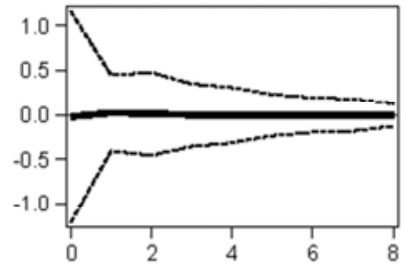

(3) Grains

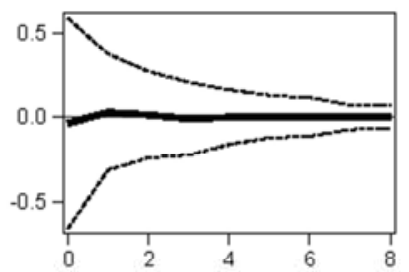

(7) Wheat

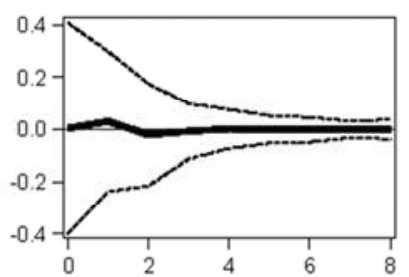

(11) Soymeal

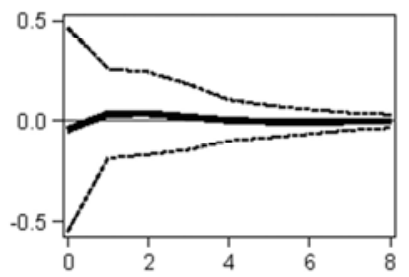

(15) Broilers

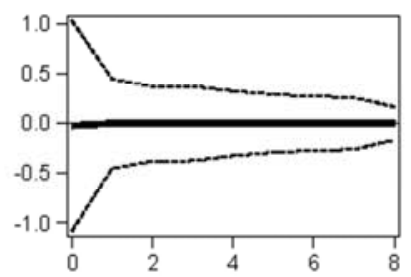

(19) Fruits (Citrus)

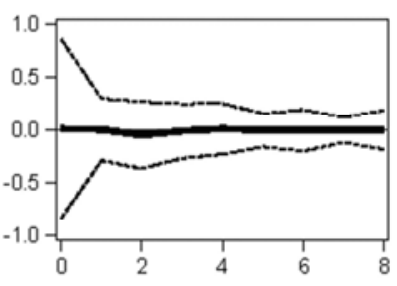

(4) Corn

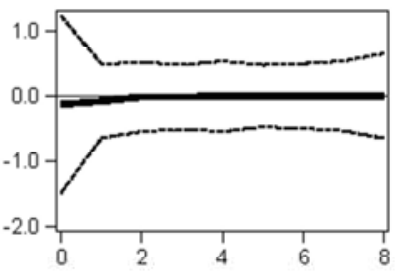

(8) Cotton

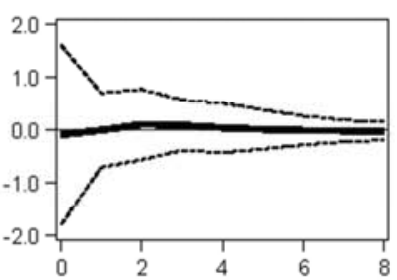

(12) Soyoil

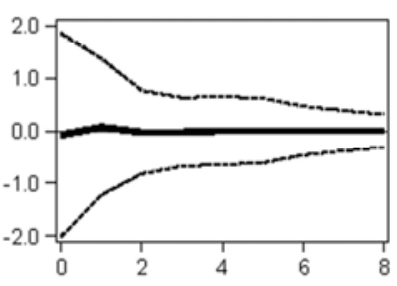

(16) Lamb

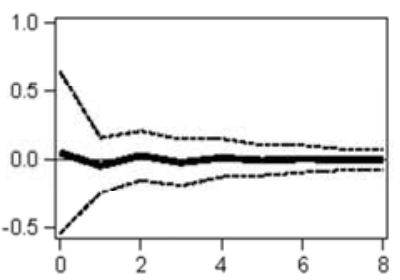

(20) Veg. (Juices)

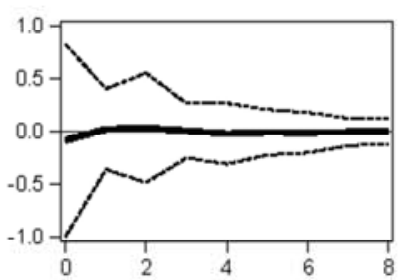

(21) Veg. (Dried)

Figure 9. Impulse response function: Real Exch. Rate $\rightarrow$ U.S. Agricultural Exports 
Table 3. Reduced-form error correction specification of U.S. agricultural export demand equations*.

\begin{tabular}{|c|c|c|c|c|c|c|c|c|c|c|c|}
\hline Commodity & Speed of Adj. & Intercept & $\Delta X_{t-1}$ & $\overline{\Delta G D P_{t-1}}$ & $\Delta R E R_{t-1}$ & $\Delta X_{t-2}$ & $\Delta G D P_{t-2}$ & $\Delta R E R_{t-2}$ & $\Delta X_{t-3}$ & $\Delta G D P_{t-3}$ & $\Delta R E R_{t-3}$ \\
\hline Total Exports & $\begin{array}{l}-0.185^{*} \\
(0.080)\end{array}$ & $\begin{array}{l}0.010 \\
(0.043)\end{array}$ & $\begin{array}{l}0.237 \\
(0.181)\end{array}$ & $\begin{array}{l}3.521^{* * 2} \\
(1.092)\end{array}$ & $\begin{array}{l}0.326 \\
(0.593)\end{array}$ & & & & & & \\
\hline Bulk Comm. & $\begin{array}{l}-0.768^{* * *} \\
(0.193)\end{array}$ & $\begin{array}{l}0.019 \\
(0.094)\end{array}$ & $\begin{array}{l}0.113 \\
(0.163)\end{array}$ & $\begin{array}{l}-1.211 \\
(1.679)\end{array}$ & $\begin{array}{l}-1.147 \\
(0.629)\end{array}$ & & & & & & \\
\hline Grains & $\begin{array}{l}-0.687^{* * *} \\
(0.126)\end{array}$ & $\begin{array}{l}-0.020 \\
(0.025)\end{array}$ & $\begin{array}{l}0.320^{*} \\
(0.150)\end{array}$ & $\begin{array}{l}-0.718 \\
(0.750)\end{array}$ & $\begin{array}{l}0.791 \\
(0.436)\end{array}$ & & & & & & \\
\hline Corn & $\begin{array}{l}-0.556^{* * *} \\
(0.122)\end{array}$ & $\begin{array}{l}-0.025 \\
(0.034)\end{array}$ & $\begin{array}{l}(0.137) \\
(0.145)\end{array}$ & $\begin{array}{l}-0.928 \\
(1.012)\end{array}$ & $\begin{array}{l}0.262 \\
(0.541)\end{array}$ & & & & & & \\
\hline Rice & $\begin{array}{l}-0.454^{* * *} \\
(0.158)\end{array}$ & $\begin{array}{l}0.001 \\
(0.055)\end{array}$ & $\begin{array}{l}-0.104 \\
(0.164)\end{array}$ & $\begin{array}{l}-3.137 \\
(1.713)\end{array}$ & $\begin{array}{l}-0.614 \\
(0.775)\end{array}$ & & & & & & \\
\hline Soybean & $\begin{array}{l}-0.520^{* *} \\
(0.108)\end{array}$ & $\begin{array}{l}-0.009 \\
(0.035)\end{array}$ & $\begin{array}{l}0.197 \\
(0.135)\end{array}$ & $\begin{array}{l}2.113^{* *} \\
(0.768)\end{array}$ & $\begin{array}{l}-0.520 \\
(0.108)\end{array}$ & & & & & & \\
\hline Wheat & $\begin{array}{l}-0.367^{* *} \\
(0.121)\end{array}$ & $\begin{array}{l}-0.016 \\
(0.043)\end{array}$ & $\begin{array}{l}-0.075 \\
(0.169)\end{array}$ & $\begin{array}{l}-0.655 \\
(1.359)\end{array}$ & $\begin{array}{l}0.531 \\
(0.463)\end{array}$ & & & & & & \\
\hline Cotton & $\begin{array}{l}-0.789^{* * *} \\
(0.195)\end{array}$ & $\begin{array}{l}0.021 \\
(0.099)\end{array}$ & $\begin{array}{l}0.112 \\
(0.162)\end{array}$ & $\begin{array}{l}-1.522 \\
(1.730)\end{array}$ & $\begin{array}{l}-1.238 \\
(0.654)\end{array}$ & & & & & & \\
\hline Tobacco & $\begin{array}{l}-0.789^{* * *} \\
(0.161)\end{array}$ & $\begin{array}{l}-0.002 \\
(0.019)\end{array}$ & $\begin{array}{l}0.083 \\
(0.145)\end{array}$ & $\begin{array}{l}0.930 \\
(0.719)\end{array}$ & $\begin{array}{l}0.659^{* *} \\
(0.232)\end{array}$ & & & & & & \\
\hline Soymeal & $\begin{array}{l}-0.313^{* * *} \\
(0.085)\end{array}$ & $\begin{array}{l}0.014 \\
(0.046)\end{array}$ & $\begin{array}{l}0.061 \\
(0.152)\end{array}$ & $\begin{array}{l}3.206^{*} \\
(1.442)\end{array}$ & $\begin{array}{l}1.314 \\
(0.703)\end{array}$ & & & & & & \\
\hline Soyoil & $\begin{array}{l}-0.777^{* * *} \\
(0.171)\end{array}$ & $\begin{array}{l}0.007 \\
(0.098)\end{array}$ & $\begin{array}{l}0.206 \\
(0.154)\end{array}$ & $\begin{array}{l}6.492^{*} \\
(2.638)\end{array}$ & $\begin{array}{l}2.560^{*} \\
(1.133)\end{array}$ & & & & & & \\
\hline High Val. Inter. & $\begin{array}{l}-0.377^{* * *} \\
(0.088)\end{array}$ & $\begin{array}{l}0.015 \\
(0.045)\end{array}$ & $\begin{array}{l}0.090 \\
(0.145)\end{array}$ & $\begin{array}{l}3.707^{* *} \\
(1.366)\end{array}$ & $\begin{array}{l}1.519^{*} \\
(0.657)\end{array}$ & & & & & & \\
\hline High Val. Proc. & $\begin{array}{l}-0.140^{*} \\
(0.059)\end{array}$ & $\begin{array}{l}0.005 \\
(0.040)\end{array}$ & $\begin{array}{l}-0.011 \\
(0.166)\end{array}$ & $\begin{array}{l}1.514 \\
(1.069)\end{array}$ & $\begin{array}{l}0.284 \\
(0.497)\end{array}$ & & & & & & \\
\hline Beef (Veal) & $\begin{array}{l}-0.161^{*} \\
(0.068)\end{array}$ & $\begin{array}{l}0.003 \\
(0.101)\end{array}$ & $\begin{array}{l}-0.045 \\
(0.160)\end{array}$ & $\begin{array}{l}-2.821 \\
(2.836)\end{array}$ & $\begin{array}{l}-1.081 \\
(0.956)\end{array}$ & & & & & & \\
\hline Broilers & $\begin{array}{l}-0.285^{* * *} \\
(0.082)\end{array}$ & $\begin{array}{l}0.002 \\
(0.057)\end{array}$ & $\begin{array}{l}0.186 \\
(0.144)\end{array}$ & $\begin{array}{l}0.452 \\
(1.491)\end{array}$ & $\begin{array}{l}0.826 \\
(0.512)\end{array}$ & & & & & & \\
\hline Lamb & $\begin{array}{l}-0.582^{* *} \\
(0.216)\end{array}$ & $\begin{array}{l}-0.006 \\
(0.108)\end{array}$ & $\begin{array}{l}0.158 \\
(0.219)\end{array}$ & $\begin{array}{l}-6.334^{* *} \\
(2.225)\end{array}$ & $\begin{array}{l}-1.422 \\
(0.850)\end{array}$ & $\begin{array}{l}0.113 \\
(0.185)\end{array}$ & $\begin{array}{l}-2.407 \\
(2.348)\end{array}$ & $\begin{array}{l}-0.700 \\
(0.881)\end{array}$ & $\begin{array}{l}0.196 \\
(0.170)\end{array}$ & $\begin{array}{l}-3.537 \\
(2.159)\end{array}$ & $\begin{array}{l}-1.983^{*} \\
(0.864)\end{array}$ \\
\hline Poultry & $\begin{array}{l}-0.251^{* *} \\
(0.094)\end{array}$ & $\begin{array}{l}0.007 \\
(0.050)\end{array}$ & $\begin{array}{l}0.185 \\
(0.155)\end{array}$ & $\begin{array}{l}-0.522 \\
(1.177)\end{array}$ & $\begin{array}{l}0.140 \\
(0.479)\end{array}$ & & & & & & \\
\hline Red Meat & $\begin{array}{l}-0.330^{* *} \\
(0.106)\end{array}$ & $\begin{array}{l}0.0001 \\
(0.068)\end{array}$ & $\begin{array}{l}-0.003 \\
(0.170)\end{array}$ & $\begin{array}{l}-3.207 \\
(2.130)\end{array}$ & $\begin{array}{l}-0.680 \\
(0.652)\end{array}$ & & & & & & \\
\hline Fruits (Citrus) & $\begin{array}{l}-0.588^{* * *} \\
(0.149)\end{array}$ & $\begin{array}{l}-0.014 \\
(0.030)\end{array}$ & $\begin{array}{l}-0.208 \\
(0.141)\end{array}$ & $\begin{array}{l}-0.497 \\
(0.952)\end{array}$ & $\begin{array}{l}-0.179 \\
(0.423)\end{array}$ & & & & & & \\
\hline Veg. (Juices) & $\begin{array}{l}-0.308^{* *} \\
(0.097)\end{array}$ & $\begin{array}{l}-0.008 \\
(0.064)\end{array}$ & $\begin{array}{l}-0.093 \\
(0.156)\end{array}$ & $\begin{array}{l}1.039 \\
(1.740)\end{array}$ & $\begin{array}{l}-0.845 \\
(1.043)\end{array}$ & & & & & & \\
\hline Veg. (Dried) & $\begin{array}{l}-0.381^{* * *} \\
(0.087)\end{array}$ & $\begin{array}{l}-0.026 \\
(0.067)\end{array}$ & $\begin{array}{l}-0.062 \\
(0.124)\end{array}$ & $\begin{array}{l}1.849 \\
(1.778)\end{array}$ & $\begin{array}{l}0.700 \\
(0.687)\end{array}$ & $\begin{array}{l}-0.096 \\
(0.121)\end{array}$ & $\begin{array}{l}-8.292^{* * *} \\
(1.708)\end{array}$ & $\begin{array}{l}-1.570^{*} \\
(0.688)\end{array}$ & & & \\
\hline
\end{tabular}

${ }^{*}$ Standard errors are in parenthesis. ${ }^{* * *}, * *$, and $*$ indicate significance at the $1 \%, 5 \%$, and $10 \%$ level, respectively. The magnitude of the speed of adjustment parameter measures the speed at which deviations from predicted long-run equilibrium are corrected to restore long-run equilibrium: a value of 0.3 implies that roughly $30 \%$ of the disequilibrium between actual and predicted exports is corrected within one time period.

\subsubsection{Impulse Response Analysis}

Structural impulse response functions of agricultural exports due to one percentage shocks to foreign GDP and real exchange rate are presented in figures 8 and 9 . The solid lines in Figure 8, for instance, trace the response of rate of growth of exports to a one percent shock to rate of growth of importers' trade-adjusted GDP. The dashed lines plot the 95\% confidence interval for the impulse response function, generated from a bootstrap procedure using 1000 replications.

Observe that a shock to rate of growth of foreign GDP (Figure 8) does not produce a permanent change in export growth rates, and disequilibrium due to a shock to foreign GDP dissipates after two years for most commodities. Export growth rate of soybean, tobacco, veal, poultry, red meat, vegetable juices, dried vegetables, and total export value display somewhat prolonged convergence, with disequilibrium due to a GDP shock lasting up to 4 years. The same is true of a one percent shock to the index of trade-weighted real exchange rate (Figure 9), where the effect of the shock may linger for 2 to 4 years. However, it is important to note that the responses are not statistically significantly different from zero, and therefore the impulse response functions should not be overinterpreted.

For several commodities, the pattern of convergence to equilibrium is complex, indicative of the complex short-run dynamics and dynamic feedback between the endogenous variables causing the effects of shocks to die out more slowly. Indeed, the oscillating pattern of convergence is suggested by the presence of multiple conjugate pairs of complex roots in the characteristic equation corresponding to the reduced form error correction models for these commodities [49]. 


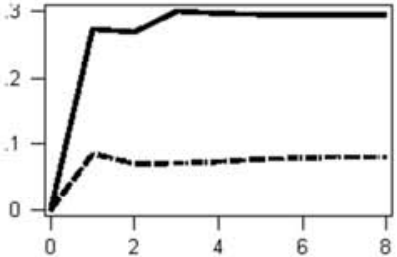

(1) Total Exp. Val.

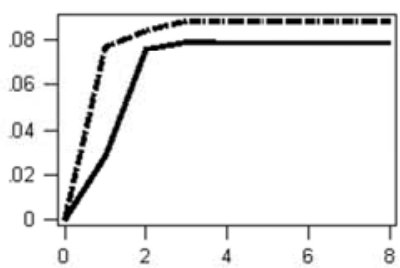

(5) Rice

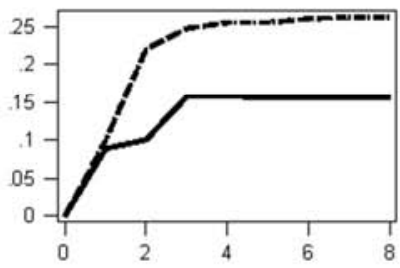

(9) Tobacco

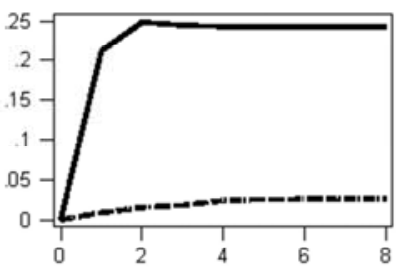

(13) High Val. Proc.

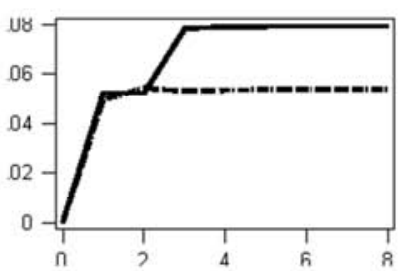

(17) Poultry

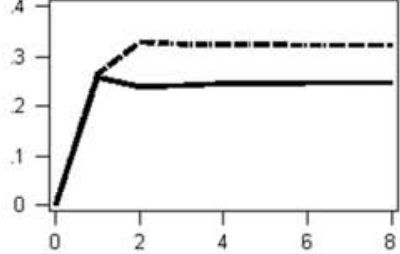

(2) Bulk Comm.

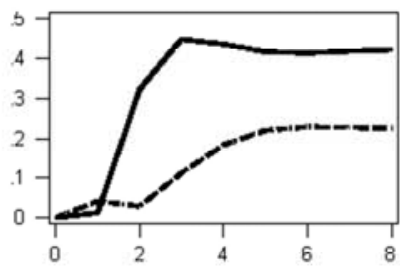

(6) Soybean

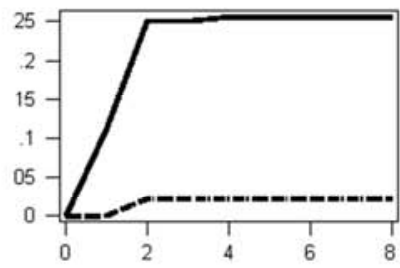

(10) High Val. Inter.

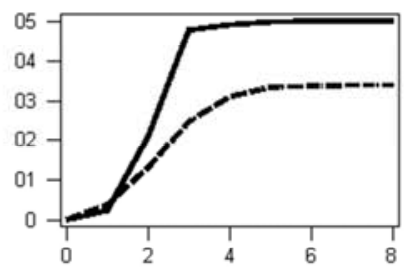

(14) Beef (Veal)

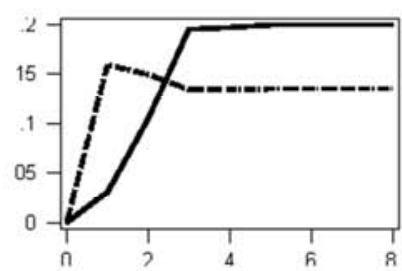

(18) Red Meat

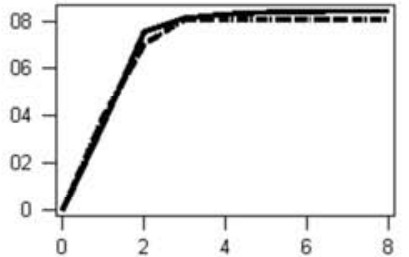

(3) Grains

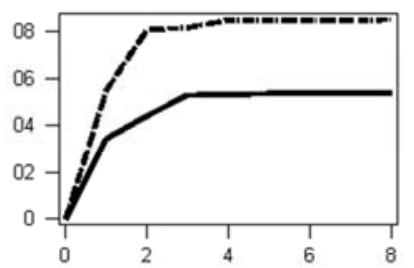

(7) Wheat

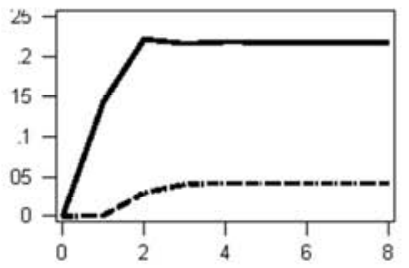

(11) Soymeal

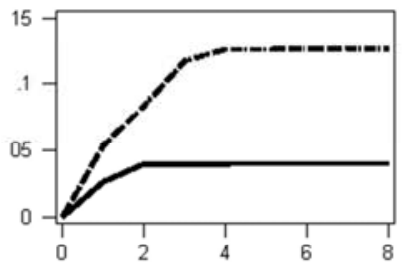

(15) Broilers

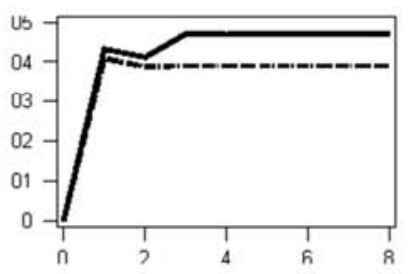

(19) Fruits (Citrus)

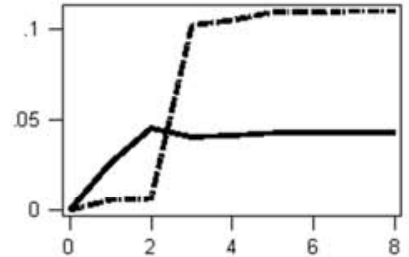

(4) Corn

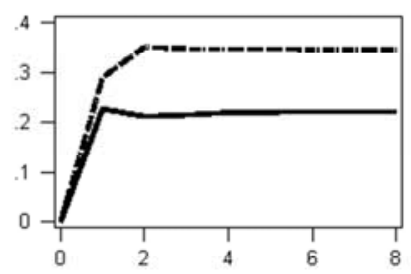

(8) Cotton

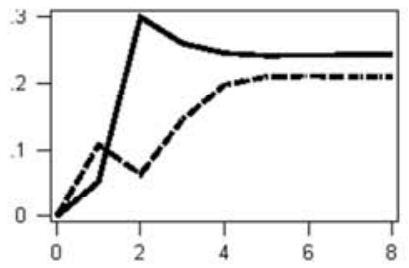

(12) Soyoil

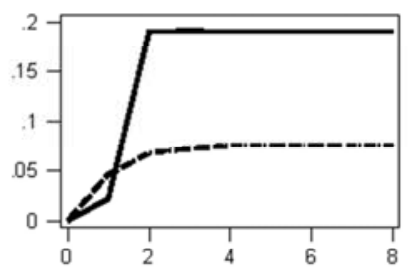

(16) Lamb

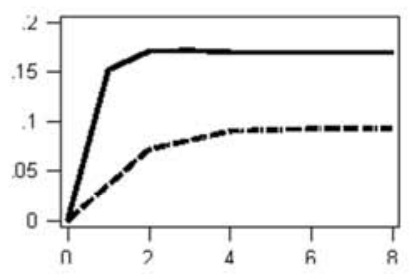

(20) Veg. (Juices)

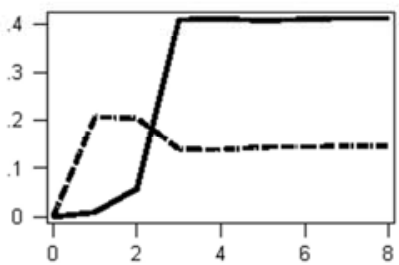

(21) Veg. (Dried)

Figure 10. Forecast error variance decomposition of U.S. agricultural export growth

\subsubsection{Forecast Error Variance Decomposition Analysis}

Structural FEVDs showing the decomposition of variance in export growth due to shocks to growth of foreign GDP and exchange rate are presented in Figure 10. The solid line plots the share of variance in U.S. agricultural exports attributable to structural innovations in importers' trade-adjusted GDP, while the dashed lines plot the share of variance in U.S. 
agricultural exports attributable to structural innovations in the real exchange rate. Exogenous shocks to agricultural exports account for the largest share of forecast error variance in export growth; similar results are found for agricultural exports in Nigeria [50]. Even though shocks to foreign GDP and real exchange rate account for successively larger proportions of the forecast error variance of most commodity exports, the largest proportion of forecast error variance in exports continue to arise from effects within the agricultural sector [51].

Notable exceptions are bulk commodity exports and cotton, where exchange rate fluctuations account for $30 \%-40 \%$ of the forecast error variance in exports; for soybean and dried vegetable exports, shocks to foreign GDP account for slightly more than $40 \%$ of the forecast error variance in export growth.

\section{Conclusion}

In the aftermath of the global financial crisis, there has been a resurgence of interest in examining the links between trade volumes, exchange rate fluctuations, and macroeconomic fundamentals. Investigating the relationship between exchange rate variability and export diversification in Tanzania and Ethipia, Wondemu and Potts [52] find that undervaluation of the real exchange rate increases demand for the countries' exports and also boosts export diversification. In a recent report, Liefert, Mitchell, and Seeley [53] argue that economic crisis reduce a country's agricultural imports through two main channels: first by lowering gross domestic product which reduces demand for imports, and second by a depreciation of the country's currency which increases the relative price of imports to domestic substitutes thereby decreasing import demand. Valdes, Hjort, and Seeley [54] find that currency depreciation in Brazil increase Brazil's agricultural exports. Similar results have been found for the Swiss agriculture and food sector [55].

In this paper, we develop a structural model of foreign demand for U.S. agricultural exports, foreign GDP, and real exchange rate volatility to examine the sector's international competitiveness and opportunities for export extensification. Estimates of long-run elasticities suggest that exports of high-value processed agricultural products are more sensitive to changes in foreign income and exchange rate fluctuations than exports of low-value grains and bulk commodities. Thus, equal growth across all importing countries leads to a smaller increase in U.S. exports of bulk commodities than high-value processed commodities, and real appreciation of the dollar leads to a more than proportionate decline in U.S. exports of processed meats and vegetables relative to bulk exports.

Analysis of short-run dynamics substantiates the existence of a stable structural export demand equation for exports of 21 out of 32 commodities in our sample. We also find that, on average, exports of grains and bulk commodities converge to long-run equilibrium at a faster rate than exports of high-value processed commodities. This has (substantively and statistically) significant implications for U.S. agricultural policy: U.S. agricultural exports may benefit not only from policies intended to increase trade with existing developing country importers but also from policies that aim to export agricultural commodities to emerging markets (i.e., export market diversification along both intensive and extensive margins).

Finally, our modeling framework highlights the importance of including the long-run relationship when modeling the short-run dynamics. Our results suggest that, first, long-run elasticity estimates by themselves are insufficient to track and explain the complex short-run dynamics of innovations in endogenous variables. Second, even though the mechanics of the equilibrating process are not precisely captured, the cointegrating vector autoregressive framework incorporates insights from economic theory and both short- and long-run parameter estimates, accounting for the complex interrelationships among the core macroeconomic variables.

Two caveats deserve mention. First, high income elasticity for high-value processed exports and low-income elasticity for bulk exports does not necessarily mean that economic growth in high-income countries benefits U.S. agriculture more than economic growth in low-income countries. Similarly, low (absolute) exchange rate elasticity for bulk exports and high exchange rate elasticity for processed food exports should not lead one to conclude that the magnitude of the increase in bulk exports due to depreciation against currencies of developing countries is smaller than the increase in processed meat and vegetable exports associated with a commensurate depreciation against developed countries' currencies.

We caution against such potentially fallacious interpretations. First, long-run elasticity estimates may be substantively biased due to aggregation across vastly diverse export destinations. A more appropriate strategy to address this question will be to model developing and developed countries separately, especially so if the rise in developing countries' demand for U.S. agricultural products- fueled by rapid economic growth in developing countries- outweighs the high income elasticity of agricultural exports to developed countries.

Finally, interactions among variables in a macroeconomic model are often far more complex than what is captured by long-run equilibrium relations alone; studying the short-run transition dynamics provides a richer understanding of the underlying structure of the model. For example, while depreciation of developed countries' currencies may produce a larger increase in exports of processed foods relative to grains, we have shown that relative to developed countries, developing countries are more resilient to exogenous shocks and disequilibrium errors are corrected quickly.

\section{Acknowledgements}

The authors wish to express their gratitude to Peter Hess, Clark Ross, Dave Martin, Shyam Gouri Suresh, William Collins, Fred Smith, Matthew Shane, Raja Kali, Rodney Smith, Gopinath Munisamy, Donguul Choi, and seminar 
participants at the University of Arkansas for helpful comments and suggestions. Trent Turbyfill provided excellent research assistance. The authors also gratefully acknowledge support from the United States Department of Agriculture, Economic Research Service (58-3000-2-0013).

\section{References}

[1] World Trade Organization (2014) Trade and Development Recent Trends and the Role of the WTO. (Technical Report).

[2] Cooke, B., Nigatu, G., Heerman, K., Landes, M., \& Seeley, R. (2016) Global Macroeconomic Developments Drive Downturn in U.S. Agricultural Exports. U.S. Department of Agriculture, Economic Research Service (Technical Report) AES-94.

[3] Liefert, W. M., \& Shane, M. (2009) The World Economic Crisis and U.S. Agriculture: From Boom to Gloom? Choices, 24 (1), 22-26.

[4] Josling, T., Anderson, K., Schmitz, A., \& Tangermann, S. (2010) Understanding international trade in agricultural products: One hundred years of contributions by agricultural economists. American Journal of Agricultural Economics, 92 (2), 424-446.

[5] Schuh, G. E. (1974) The Exchange Rate and U. S. Agriculture. American Journal of Agricultural Economics, 56 (1), 1-13.

[6] Karp, L. S. \& Perloff, J. M. (2002) A synthesis of agricultural trade economics. Handbook of Agricultural Economics, 2, 1945-1998.

[7] Orden, D. (2010) Recent Macroeconomic Dynamics and Agriculture in Historical Perspective. Journal of Agricultural and Applied Economics 42 (3), 467-476.

[8] Shane, M. D., Roe, T. L., \& Somwaru, A. L. (2008) Exchange Rates, Foreign Income, and U.S. Agricultural Exports. Agricultural and Resource Economics Review, 37 (2), 160175.

[9] Baek, J. \& Koo, W. W. (2011) How sensitive is U.S. agricultural trade to the bilateral exchange rate? Evidence from bulk, intermediate, and consumer-oriented products. Agricultural Economics, 42 (3), 387-403.

[10] Ardeni, P. G. \& Freebairn, J. (2002) The Macroeconomics of Agriculture. Handbook of Agricultural Economics, 2, 127 142 .

[11] Baek, J. \& Koo, W. W. (2009) Assessing the Exchange Rate Sensitivity of U.S. Bilateral Agricultural Trade. Canadian Journal of Agricultural Economics, 57 (2), 187-203.

[12] Baek, J., Koo, W. W., \& Mulik, K. (2009) Exchange Rate Dynamics and the Bilateral Trade Balance: The Case of U.S. Agriculture. Agricultural and Resource Economics Review, 38 (2), 213-228.

[13] Kim, M., Cho, G. D., \& Koo, W. W. Does the Exchange Rate Matter to Agricultural Bilateral Trade between Canada and the U.S.? Canadian Journal of Agricultural Economics, 52 (1), $127-145$.

[14] Awokuse, T. O. (2005) Impact of macroeconomic policies on agricultural prices. Agricultural and Resource Economics
Review, 34 (2), 226-237.

[15] Bahmani-Oskooee, M. \& Wang, Y. (2007) United States-China Trade At the Commodity Level and the Yuan-Dollar Exchange Rate. Contemporary Economic Policy, 25 (3), 341-361.

[16] Baek, J. \& Koo, W. W. (2008) Identifying macroeconomic linkages to U.S. agricultural trade balance. Canadian Journal of Agricultural Economics, 56 (1), 63-77.

[17] Saghaian, S. H., Reed, M. R., \& Marchant, M. A. (2002) Monetary impacts and overshooting of agricultural prices in an open economy. American Journal of Agricultural Economics, 84 (1), 90-103.

[18] Kwon, D. H. \& Koo, W. W. (2009) Interdependence of Macro and Agricultural Economics: How Sensitive is the Relationship? American Journal of Agricultural Economics, 91 (5), 1194-1200.

[19] Algieri, B. (2014) A roller coaster ride: An empirical investigation of the main drivers of the international wheat price. Agricultural Economics, 45 (4), 459-475.

[20] Devadoss, S., Hilland, A., Mittelhammer, R., \& Foltz, J. (2014) The effects of the Yuan-dollar exchange rate on agricultural commodity trade between the United States, China, and their competitors. Agricultural Economics, 45 (S1), 23-37.

[21] Gutierrez, L., Piras, F., \& Roggero, P. P. (2015) A Global Vector Autoregression Model for the Analysis of Wheat Export Prices. American Journal of Agricultural Economics, 97 (5), 1494-1511.

[22] Chambers, R. G. \& Just, R. E. (1981) Effects of Exchange Rate Changes on U.S. Agriculture: A Dynamic Analysis. American Journal of Agricultural Economics, 63 (1), 32-46.

[23] Pesaran, M. H., Shin, Y., \& Smith, R. J. (2001) Bounds testing approaches to the analysis of level relationships. Journal of Applied Econometrics, 16 (3), 289-326.

[24] Hylleberg, S. \& Mizon, G. E. (1989) Cointegration and Error Correction Mechanisms. The Economic Journal, 99 (395), 113-125.

[25] Garratt, A., Lee, K. C., Pesaran, M. H., \& Shin, Y. (1998) A Structural Cointegrating VAR Approach to Macroeconometric Modelling. Edinburgh School of Economics Discussion Paper 8.

[26] Sims, C. A. (1980) Macroeconomics and Reality. Econometrica, 48 (1), 1-48.

[27] U.S. Department of Agriculture. Global Agricultural Trade System Online. https://apps.fas.usda.gov/gats/default.aspx. Foreign Agriculture Service, USDA. (Data).

[28] The World Bank. World Development Indicators: https://datacatalog.worldbank.org/dataset/world-developmentindicators. (Data).

[29] United States Department of Agriculture (2017) Agricultural Exchange Rate Data Set: https://www.ers.usda.gov/data-products/agricultural-exchange -rate-data-set/. Economic Research Service, USDA (Data).

[30] Senhadji, A. S. \& Montenegro, C. E. (1999) Time Series Analysis of Export Demand Equations: A Cross-Country Analysis. IMF Staff Papers, 46 (3), 259-273. 
[31] Esfahani, H. S., Mohaddes, K., \& Pesaran, M. H. (2014) An Empirical Growth Model for Major Oil Exporters. Journal of Applied Econometrics, 29, 1-21.

[32] Enders, W. (2004) Applied Econometric Time Series. John Wiley \& Sons.

[33] Kwiatkowski, D., Phillips, P. C., Schmidt, P., \& Shin, Y. (1992) Testing the null hypothesis of stationarity against the alternative of a unit root. Journal of Econometrics, 54, 159178.

[34] Akaike, H. (1998) Information Theory and an Extension of the Maximum Likelihood Principle. Selected Papers of Hirotugu Akaike (E. Parzen, K. Tanabe, and G. Kitagawa, eds.), Springer Series in Statistics, New York, NY: Springer New York.

[35] Schwarz, G. (1978) Estimating the Dimension of a Model. The Annals of Statistics, 6 (2), 461-464.

[36] Hannan, E. J. \& Quinn, B. G. (1979) The Determination of the Order of an Autoregression. Journal of the Royal Statistical Society. Series B (Methodological), 41 (2), 190-195.

[37] Durbin, J. (1970) Testing for serial correlation in least-squares regression when some of the regressors are lagged dependent variables. Econometrica, 38 (3), 410-421.

[38] Lutkepohl, H. (2005) New Introduction to Multiple Time Series Analysis. Springer: Berlin, Heidelberg.

[39] Stata Corp (2013) Stata Base Reference Manual, 13. College Station, TX: Stata Press.

[40] Baum, C. F. (2006) An Introduction to Modern Econometrics using Stata. StataCorp LP.

[41] Christian, P. (2015) The Distributional Consequences of Group Procurement: Evidence from a Randomized Trial of a Food Security Program in Rural India. The Distributional Consequences of Group Procurement, The World Bank.

[42] Krugman, P. (1989) Differences in income elasticities and trends in real exchange rates. European Economic Review, 33 (5), 1031-1046.

[43] Regmi, A. (2001) "Changing Structure of Global Food Consumption and Trade: An Introduction," Changing Structure of Global Food Consumption and Trade, no. Agriculture and Trade Report. WRS-01-1, 1-13.

[44] Regmi, A., Deepak, M., Seale, J.L., \& Bernstein, J. (2011)
"Cross-Country Analysis of Food Consumption Patterns," Changing Structure of Global Food Consumption and Trade, no. Agriculture and Trade Report. WRS-01-1, pp. 14-22.

[45] Meade, B., Regmi, A., Seale, J. L., \& Muhammad, A. (2014) New International Evidence on Food Consumption Patterns: A Focus on Cross-Price Effects Based on 2005 International Comparison Program Data. Technical bulletin 1937, U.S. Department of Agriculture, Economic Research Service.

[46] Kremers, J., Ericsson, N., \& Dolado, J. (1992) The Power of Cointegration Tests. Oxford Bulletin of Economics and Statistics, 54 (3), 325-48.

[47] Banerjee, A., Dolado, J., \& Mestre, R. (1998) Error-correction Mechanism Tests for Cointegration in a Single-equation Framework. Journal of Time Series Analysis, 19 (3), 267-283.

[48] Pick, D. H. (1990) Exchange Rate Risk and U.S. Agricultural Trade Flows. American Journal of Agricultural Economics, 72 (3), 694-700.

[49] Giles, D. E. (2013) Stationarity Conditions for an AR (2) Process. Department of Economics, University of Victoria, Canada (unpublished).

[50] Olusegun, O. B., \& Segun, B. L. J. (2019) Agricultural Output And Macroeconomic Policy: Examining The Delicate Linkage in Nigeria. The Journal of Developing Areas, 53 (1), 17-31.

[51] Chambers, R. G. (1984) Agricultural and Financial Market Interdependence in the Short Run. American Journal of Agricultural Economics, 66 (1), 12-24.

[52] Wondemu, K. \& Potts, D. (2016) The Impact of the Real Exchange Rate Changes on Export Performance in Tanzania and Ethiopia. African Development Bank, Working Paper No. 240, 1-39.

[53] Liefert, W. M., Mitchell, L., \& Seeley, R. (2021) Economic Crises and U.S. Agricultural Exports. U.S. Department of Agriculture, Economic Research Service, ERR-282, 1-28.

[54] Valdes, C., Hjort, K., \& Seeley, R. (2020) Brazil's Agricultural Competitiveness: Recent Growth and Future Impacts under Currency Depreciation and Changing Macroeconomic Conditions. U.S. Department of Agriculture, Economic Research Service, ERR-276, 1-43.

[55] Kohler, A. \& Ferjani, A. (2018) Exchange Rate Effects: A Case Study of the Export Performance of the Swiss Agriculture and Food Sector. The World Economy, 41 (2), 494-518. 